American Journal of Pharmacology and Toxicology 5 (4): 183-208, 2010

ISSN 1557-4962

(C) 2010 Science Publications

\title{
Uncommon Toxicologic Profile at Toxic Doses of CPI-613 (an Agent Selectively Alters Tumor Energy Metabolism) in Rats and Minipigs Reflects Novel Mechanism
}

\author{
${ }^{1,2}$ King C. Lee, ${ }^{3}$ Claudia Maturo, ${ }^{1}$ Robert Shorr and ${ }^{1}$ Robert Rodriguez \\ ${ }^{1}$ Department of Regulatory and Clinical Affairs, Cornerstone Pharmaceuticals, Inc., \\ 1 Duncan Drive, Cranbury, NJ 08512 USA \\ ${ }^{2}$ Department of Graduate Nursing Program, Faculty of Nursing, Quinnipiac University, \\ 275 Mount Carmel Avenue, Hamden, CT 06518 USA \\ ${ }^{3}$ Department of Program Management, Cornerstone Pharmaceuticals, Inc., \\ 1 Duncan Drive, Cranbury, NJ 08512 USA
}

\begin{abstract}
Problem statement: CPI-613 is a novel anticancer agent and the toxicological profile has not been assessed. Accordingly, the objective of these studies was to thoroughly evaluate the Toxicokinetic (TK) effects of CPI-613 in rats and to compare the toxicological profile of rats to minipigs to determine if there were differences between the two animal species. Approach: These studies involved assessments of multiple toxicological parameters (including clinical signs as well as full panel blood work, necropsy and histology) at multiple times in animals treated with the threshold dose (i.e., a dose that did not induce significant effects), toxic dose (i.e., a dose that induced significant toxic effects) and dose that approximated the $\mathrm{LD}_{10}$ dose (i.e., a dose that induced death in approximately $10 \%$ of the animals). CPI-613 was given intravenously $2 x$ weekly for 3 weeks, a dosing schedule that is used in clinical trials of CPI-613. CPI-613-treated animals were compared to absolute control treatment as well as vehicle treatment. Furthermore, the correlations among toxic effects of CPI-613, plasma concentrations and Pharmacokinetics (PK) of CPI-613 were evaluated to establish the TK effects of CPI-613. Results: The results demonstrated the uncommon toxicological profile at toxic doses of CPI-613, which were related to induction of inflammation as the primary and the only toxicological effects in both animal species. The induction of inflammation was consistent with the dose-related increases in plasma CPI-613. Other changes such as elevations in reticulocytes and Gamma-Glutamyl Transferase (GGT) were also observed, but they might be secondary to the inflammatory effects of CPI-613. The toxic doses of CPI-613 were $\sim 60 \mathrm{x}$ the anti-tumor dose levels observed in mouse tumor xenograft models, suggesting a wide safety margin of CPI-613. Conclusion: CPI-613 had an uncommon toxicological profile (induction of inflammation) in both animal species, which reflects its novel mechanism of action.
\end{abstract}

Key words: Gamma-Glutamyl Transferase (GGT), toxicological profile, animal species, oxidative phosphorylation, anti-cancer agents, tumor mitochondria, metabolic syndrome, systematic evaluation, hypoxic microenvironments, necrosis and autophagia, clinical pathology

\section{INTRODUCTION}

Mitochondria of tumor cells are different from that of normal cells due to re-organization of the metabolic machinery causing tumor mitochondria to generate large amounts of biosynthetic precursors to allow tumor cells to thrive in hypo-vascularized, hypoxic microenvironments (Baggetto, 1992; Kim and Dang, 2006; Ravindran et al., 1996; Sakkrom et al., 2010). The alterations of tumor mitochondria include changes in mitochondrial membrane lipid contents, shifting reliance on glycolysis from oxidative phosphorylation as the primary sources of deriving ATP and changes in mitochondrial enzymes such as Pyruvate Dehydrogenase (PDC) and $\alpha$-Ketoglutarate Dehydrogenase (KDH) (Kroemer and Pouyssegur, 2008).

CPI-613 is a novel anti-cancer agent with mechanism of action that does not belong to any existing pharmacological class of anti-cancer agents currently used in the clinics and CPI-613 is referred to

Corresponding Author: King Lee, Cornerstone Pharmaceuticals, Inc., 1 Duncan Drive, Cranbury, NJ 08512, USA

Tel: 1-609-409-6037 Fax: 1-631-444-6895 
Am. J. Pharm. \& Toxicol., 5 (4): 183-208, 2010

as an Altered Energy Metabolism-Directed (AEMD) compound. Although structurally similar to lipoate, CPI-613 has activities that are distinctively different from lipoate. Specifically, CPI-613 selectively targets the altered form of mitochondrial energy metabolism found in tumor cells, causing changes in mitochondrial enzyme activities and redox status which lead to apoptosis, necrosis and autophagia of tumor cells and yet not affecting the mitochondrial energy metabolism of normal cells (Baggetto, 1992; Kroemer and Pouyssegur, 2008; Holmuhamedov et al., 2002; Sakkrom et al., 2010). These activities of CPI-613 are due to its involvement in the catalytic and regulatory functions of the tumor or altered form of $\mathrm{PDC}$ and $\mathrm{KDH}$ found in tumor cells (Kroemer and Pouyssegur, 2008).

Consistent with the proposed novel mechanism is the fact that CPI-613 has been shown to have antitumor activity in cell culture and animal tumor models against diverse cancers independent of multiple drug resistance. The novelty in the presumed mechanism of action for CPI-613 is further supported by the results from ex vivo studies demonstrating that CPI-613 is effective against various types of tumor cells excised from patients that displayed varying levels of resistance to different anti-cancer drugs currently used in the clinics. The fact that the anti-tumor activities of CPI613 are independent of the degree of tumor cell resistance to the drugs currently used in the clinic support the notion that none of the clinically used drugs have a mechanism of action similar to that of CPI-613. The significance of CPI-613 having a novel mechanism of action that is not shared by any existing pharmacological class of anti-cancer agents currently used in the clinics is that CPI-613 is effective not only against naive tumors that have never been treated with any anti-cancer agents, but also effective against tumors that are resistant to anti-cancer agents currently used in the clinics. This is an important aspect because tumors frequently develop resistance to anti-cancer agents, limiting treatment options. The availability of such a novel anti-cancer agent would provide a new tool to treat cancer. Furthermore, CPI-613 activity is independent of cell cycle phase and signal transduction pathways. This provides CPI-613 ubiquitous efficacy against diverse cancer types, even in the presence of multiple drug resistance.

Because of the novel mechanism of action and effectiveness against a variety of tumor types, CPI-613 is undergoing clinical development as an anti-cancer agent. Early clinical results regarding CPI-613 being an anti-tumor therapy are encouraging. In spite of the attractive anti-tumor effects, the Toxicokinetic (TK) effects of CPI-613 have not been thoroughly and systemically investigated. Accordingly, the objective of the studies reported here was to perform a thorough and systematic evaluation of the TK CPI-613 in rats. The objective of this study was also to investigate the toxicological effects of CPI-613 in minipigs, for determining if there were differences in the toxicological profile of CPI-613 between these two animal species. These studies involved frequent assessments of multiple toxicological parameters including clinical signs, full panel blood work, full panel necropsy and full panel histology in animals treated with the threshold dose (i.e., a dose that did not induce significant effects), toxic dose (i.e., a dose that induced significant toxic effects) and dose that approximated the $\mathrm{LD}_{10}$ dose (i.e., a dose that induced death in approximately $10 \%$ of the animals). CPI-613 was given intravenously (IV) $2 \mathrm{x}$ weekly for 3 weeks, a dosing schedule that is used in clinical trials of CPI613. The results from CPI-613-treated animals were compared to absolute control treatment as well as vehicle treatment. Furthermore, the correlations among toxic effects of CPI-613, plasma concentrations and Pharmacokinetics (PK) of CPI-613 were evaluated to establish the TK effects of CPI-613. These studies demonstrated the uncommon toxicological profile at toxic doses of CPI-613, which were related to induction of inflammation as the primary and possibly the only toxicological effects in both animal species. The induction of inflammation was consistent with the doserelated increases in plasma CPI-613. Other changes such as elevations in reticulocytes and GammaGlutamyl Transferase (GGT) were also observed, but they might be secondary to the inflammatory effects of CPI-613. The results from these studies further indicated that the toxic doses of CPI- 613 were $\sim 60 \mathrm{x}$ the anti-tumor dose levels observed in mouse tumor xenograft models, suggesting a wide safety margin of CPI-613.

\section{MATERIALS AND METHODS}

Drugs and vehicles: CPI-613 Injection (Cornerstone Pharmaceuticals, Inc.) was provided in $10-\mathrm{mL}$ injectable formulation at a concentrated form of 50 $\mathrm{mg} / \mathrm{mL}$. In the morning of each day of dosing, CPI-613 Injection was diluted to specific concentrations with diluent (5\% Dextrose in Water [D5W]) prior to IV administration. Samples of the dosing solutions of CPI613 used in CPI-613-treated animals were collected and stored until analysis for the concentration was performed to confirm the amount of CPI-613 in the dosing solution. Vehicle (Cornerstone Pharmaceuticals, Inc.) had the same composition as CPI-613 Injection, except with the absence of CPI-613. Vehicle was also diluted with $\mathrm{D} 5 \mathrm{~W}$ in the same manner as the highest dose of CPI-613 prior to IV administration. 
Am. J. Pharm. \& Toxicol., 5 (4): 183-208, 2010

Table 1: Study design and treatment groups for studies using minipigs or rats.

\begin{tabular}{|c|c|c|c|c|c|c|c|}
\hline \multirow[b]{2}{*}{ Experiments } & \multirow[b]{2}{*}{ Group } & \multirow{2}{*}{$\begin{array}{l}\text { Test } \\
\text { Article }^{a}\end{array}$} & \multicolumn{2}{|c|}{ Dose of CPI-613/Injection ${ }^{\mathrm{b}}$} & \multicolumn{2}{|c|}{ \# Animals } & \multirow[b]{2}{*}{ Day of Euthanasia $^{\mathrm{d}}$} \\
\hline & & & $\mathrm{mg} \mathrm{kg}^{-1}$ & $\mathrm{mg} \mathrm{m}^{-2}$ & Male & Females & \\
\hline A & 1 & D5W & $0^{\mathrm{c}}$ & 0 & 24 & 24 & $50 \%$ on Day $21 / 22$ and the other \\
\hline (Assessment of & 2 & Vehicle & $0^{\mathrm{c}}$ & 0 & 24 & 24 & $50 \%$ on Day $32 / 33$ \\
\hline Dose-Related & 3 & & $25^{\mathrm{c}}$ & 150 & 12 & 12 & Day $21 / 22^{\mathrm{e}}$ \\
\hline Toxicity, PK and & 4 & CPI-613 & $30^{\mathrm{c}}$ & 180 & 24 & 24 & $50 \%$ on Day $21 / 22$ and the other \\
\hline Recovery in Rats) & 5 & & $35^{\mathrm{c}}$ & 210 & 24 & 24 & $50 \%$ on Day $32 / 33$ \\
\hline B & 1 & D5W & 0 & 0 & 4 & 4 & Day $21 / 22$ \\
\hline (Assessment of & 2 & Vehicle & 0 & 0 & 4 & 4 & Day $21 / 22$ \\
\hline Dose-Related & 3 & & 45 & 1575 & 4 & 4 & Day $21 / 22$ \\
\hline Toxicity in & 4 & CPI-613 & 50 & 1750 & 4 & 4 & Day $21 / 22$ \\
\hline Minipigs) & 5 & & 55 & 1925 & 4 & 4 & Day $21 / 22$ \\
\hline
\end{tabular}

$\mathrm{D} 5 \mathrm{~W}=5 \%$ dextrose in water; $\mathrm{PK}=$ pharmacokinetic; ${ }^{a}$ : The test and control articles were administered intravenously twice weekly for three consecutive weeks, starting on day $1 ;{ }^{\text {b }}$ : Conversion of the dose from $\mathrm{mg} / \mathrm{kg}$ to $\mathrm{mg} / \mathrm{m}^{2}$ was according to Freireich's conversation (Freireich et al., 1966); ': Spare rats were available and used to replace rats that died or were euthanized during the study, so that the sample size for each treatment group remained to be 12 males and 12 females at the end of the study; ${ }^{d}$ : Upon euthanasia, gross necropsy, organ weights and histopathology were performed; ': There is no recovery group for Group 3 in rats because the dose of CPI-613 in this group was expected to induce minimum or no effects according to preliminary experiments. Therefore, there was hardly any recovery information that could be obtained from this group.

Animals: Adult laboratory-bred albino rats (SpragueDawley Harlan Indianapolis, Indiana; $\sim 250$ g body weight, both sexes) and Hanford miniature swine (Sinclair Research Center, Inc., Auxvasse, Missouri; $22-70 \mathrm{~kg}$ for males and $16-58 \mathrm{~kg}$ for females, at least 4months old) that were free from common domestic swine diseases (e.g., leptospirosis, brucellosis, pseudorabies, transmissible gastroenteritis, porcine reproductive respiratory syndrome, toxoplasmosis) (Nunoya et al., 2007; Swindle, 2007) were used. Rats were individually housed in stainless steel cages whereas minipigs were housed in separate chain-link runs with vinyl-coated elevated grating. Food (Certified Rodent Chow and Pig Diet, respectively, PMI Feeds Inc. ${ }^{\circledR}$, Richmond, IN) was available ad libitum for rats and provided using a pre-measured scoop for minipigs. Filtered tap water was available ad libitum for both species. The food and water were routinely analyzed to confirm a lack of unacceptable levels of contaminants. These analyses included detection of heavy metals, pesticides, aflatoxins and other environmental pollutants for food and heavy metals, pesticides and microbological contents for water. The rooms were well ventilated ( $>10$ air changes per hour, with $100 \%$ nonrecirculated fresh air), temperature controlled at 16$27^{\circ} \mathrm{C}$ for minipigs and $18-26^{\circ} \mathrm{C}$ for rats and relative humidity maintained at $30-70 \%$ for both species. Each room had a 12-h light/dark photoperiod. Prior to study initiation, rats were acclimated for at least 6 days whereas minipigs were acclimated to laboratory conditions for at least 25 days. Minipigs were further acclimated to sling restraint for 2 days. Handling and care of the animals were according to the USDA Animal Welfare Act (9 CFR 1 and 2) and the Guidelines for Care and Use of Laboratory Animals (National Academy Press, Washington, DC, 1996).
Experimental design: These studies included two major experiments in rats and minipigs and the designs of these experiments were as outlined in Table 1. Briefly, the animals were randomly assigned to different groups by a computer generated weightordered distribution such that group mean body weights generally did not exceed $\pm 10 \%$ of the overall mean weight for each sex. Diluent (i.e., D5W) was administered to the absolute control groups, vehicle was administered to control groups and various doses of CPI-613 were administered to CPI-613 treated groups, given $2 \mathrm{x}$ weekly (with at least 2 days between dosing) for three consecutive weeks.

Test and control articles were administered as IV bolus using asceptic technique via a venous access port which had been surgically implanted into the jugular vein in minipigs and the femoral vein in rats for IV administration. The venous access ports remained with the animals throughout the study. In minipigs, the dose volume for all animals was $5 \mathrm{~mL} \mathrm{~kg}^{-1}$ and the concentrations of CPI-613 were 9-10 and $11 \mathrm{mg}^{-1} \mathrm{~mL}$ for the $45-50$ and $55 \mathrm{mg} \mathrm{kg}^{-1}$ dose levels, respectively. In rats, the dose volume for all animals was $10 \mathrm{~mL} \mathrm{~kg}^{-1}$ and the concentrations of CPI-613 were $2.5-3.0$ and $3.5 \mathrm{mg}^{-1} \mathrm{~mL}$ for the $25-30$ and $35 \mathrm{mg} \mathrm{kg}^{-1}$ dose levels, respectively.

Potential toxicological effects of CPI-613 were evaluated by monitoring the following parameters: clinical signs, body weight, clinical pathology (chemistry and hematology), ECG (minipigs only), gross necropsy, organ weights and histopathology at various times as shown in Table 2.

Plasma CPI-613 concentrations were also assessed in rats at time points as shown in Table 2. Significant changes in toxicological parameters were correlated with plasma CPI-613 concentrations and PK to assess the TK effects of CPI-613 in rats. 
Am. J. Pharm. \& Toxicol., 5 (4): 183-208, 2010

Table 2: Parameters monitored during the studies in Experiments A and B in rats and minipigs, respectively

\begin{tabular}{|c|c|c|}
\hline & Parameters & Timing of evaluation \\
\hline \multirow[t]{8}{*}{$\begin{array}{l}\text { Toxicological } \\
\text { Parameters }\end{array}$} & Clinical Signs & $\begin{array}{l}\text { Pretest, once daily and frequently if a change was noted. On days of dosing, } \\
\text { clinical observation was performed for several hours post-dose. }\end{array}$ \\
\hline & Mortality/Moribundity & Evaluated twice daily (a.m. and p.m.) \\
\hline & Body Weight & $\begin{array}{l}\text { Pretest, on Study Day 1, predose on days of dosing, weekly during the recovery } \\
\text { period, prior to terminal fasting and prior to necropsy. }\end{array}$ \\
\hline & Food Consumption & Assessed weekly. \\
\hline & $\begin{array}{l}\text { Clinical Pathology (chemistry } \\
\& \text { hematology) (see Table 3) }\end{array}$ & $\begin{array}{l}\text { Pre-dose on Day } 1 \text { (i.e., baseline), prior to the } 4^{\text {th }} \text { dose; Study Day } 22 \text { (prior to } \\
\text { necropsy, if took place); and Study Day } 33 \text { (prior to necropsy, for the recovery } \\
\text { animals in Experiment A only). }\end{array}$ \\
\hline & CK Isoenzymes and Troponin I & $\begin{array}{l}\text { At } 0.5 \text { (minipigs only), } 1 \text { (minipigs only), } 2 \text { (minipigs only), } 4,8,16 \text { and } 24 \mathrm{~h} \\
\text { after the 1st, } 4 \text { th and } 6 \text { th dose. Also prior to euthanasia on Study Day } 22 \text { in }\end{array}$ \\
\hline & ECG & $\begin{array}{l}\text { Experiments A and B and on Study Day } 33 \text { in recovery animals in Experiment A. } \\
60 \text {-sec recording obtained pre-dose and every } 30 \text { min during the first } 3 \mathrm{~h} \text { after the } 1^{\text {st }} \text {, } \\
\text { 4th and 6th dose, as well as prior to euthanasia on Study Day } 22 \text {. (Note: ECG was } \\
\text { recorded in minipigs of Experiment B only, not in rats of Experiment A.) }\end{array}$ \\
\hline & $\begin{array}{l}\text { Gross necropsy, organ weights and } \\
\text { histopathology (Table } 3 \text { ) }\end{array}$ & $\begin{array}{l}\text { Day } 22 \text { (for Experiments A and B) or Day } 33 \text { (in recovery animals in } \\
\text { Experiment A). }\end{array}$ \\
\hline $\begin{array}{l}\text { Pharmacokinetic } \\
\text { Parameters }\end{array}$ & Plasma CPI-613 levels & $\begin{array}{l}\text { At } 0.5,1,2,4,8,16 \text { and } 24 \mathrm{~h} \text { associated with the } 1 \mathrm{st}, 2 \mathrm{nd}, 4 \text { th and } 6 \text { th doses of CPI- } 613 \\
\text { in rats. } \\
\text { minipigs of Experiment B.) }\end{array}$ \\
\hline
\end{tabular}

Assays and measurements: Clinical pathology was evaluated by performing serum chemistry and hematology assays. These assays were performed on samples collected from all animals of all treatment groups, as listed in Table 1 . Blood samples $(\sim 1.5 \mathrm{~mL}$ from rats and $\sim 2.5 \mathrm{~mL}$ from minipigs) were collected by puncture of the orbital sinus or by cardiac puncture in rats and from the venous access port or via a venous puncture in minipigs, after food was withheld for at least eight hours. The chemistry assay was performed using the automated Olympus AU840e analyzer on serum $(\sim 0.5 \mathrm{~mL})$ isolated from blood samples, whereas the hematology assay was performed using the automated ADVIA 120 analyzer on EDTAcontaining blood $(\sim 0.5 \mathrm{~mL}$ in rats and $\sim 2 \mathrm{~mL}$ in minipigs). The parameters for serum chemistry and hematology that were assessed are listed in Table 3.

In minipigs, ElectroCardiogram (ECG) was also assessed. ECG was performed with the minipigs placed in slings and ECG tracings (60-sec intervals which varied slightly in some animals due to behavior) were obtained using 6 triangular leads [e.g., dorsal, axial, ventral, aVR-dorsal, aVL-axial and aVF-ventral leads] at a chart speed of $50 \mathrm{~mm} / \mathrm{sec}$ from all animals. Measurements were taken from the axial lead.

Plasma CPI-613 concentrations were assayed as described below. Blood samples $(\sim 1 \mathrm{~mL})$ for evaluation of plasma CPI-613 levels were collected into tubes containing $\mathrm{K}_{3}$-EDTA. The blood samples were centrifuged and the plasma was extracted. The plasma samples were stored at $-70^{\circ} \mathrm{C}$ until assay. In the analysis of the concentration of CPI-613, samples were prepared using solid phase extraction to obtain the total amount (free and bound) of CPI-613, followed by analysis via a Liquid Chromatography (LC)/Mass Spectrometry (MS) $\mathrm{MS}^{-1}$ method using negative turbo ionspray ionization and operating the instrument in the Multiple-ReactionMonitoring (MRM) mode. The parameters and instruments for the $\mathrm{LC}^{-1} \mathrm{MS}^{-1} \mathrm{MS}^{-1}$ assay are listed in Table 4. Using D14 isotope of CPI-613 as the internal standard, the plasma assay for two concentration ranges

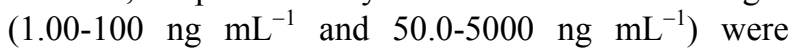
validated for sufficient linearity, specificity, reproducibility, accuracy, precision, stability at room and refrigeration temperature.

Gross necropsy, organ weights and histopathology evaluations were performed. For these evaluations, animals were humanely euthanized (via carbon dioxide asphyxiation in rats and via anesthesia with Telazol ${ }^{\circledR}$ followed by an overdose of sodium pentobarbital and then exsanguination in minipigs). Full panel necropsy was performed, which included examination of the carcass and musculoskeletal system, all external surfaces and orifices, cranial cavity and external surface of the brain, thoracic, abdominal and pelvic cavities with their associated organs and tissues.

For organ weight determination, the weights of the following organs were determined: adrenal gland, brain, heart, kidney, liver, lung, ovary, spleen, testis and thymus. Paired organs were weighed together. Organ weights were not recorded for animals that died or were euthanized prior to scheduled termination. 
Am. J. Pharm. \& Toxicol., 5 (4): 183-208, 2010

Table 3: Parameters for clinical pathology, organ weights and histology assessment in Experiments A and B in rats and minipigs, respectively

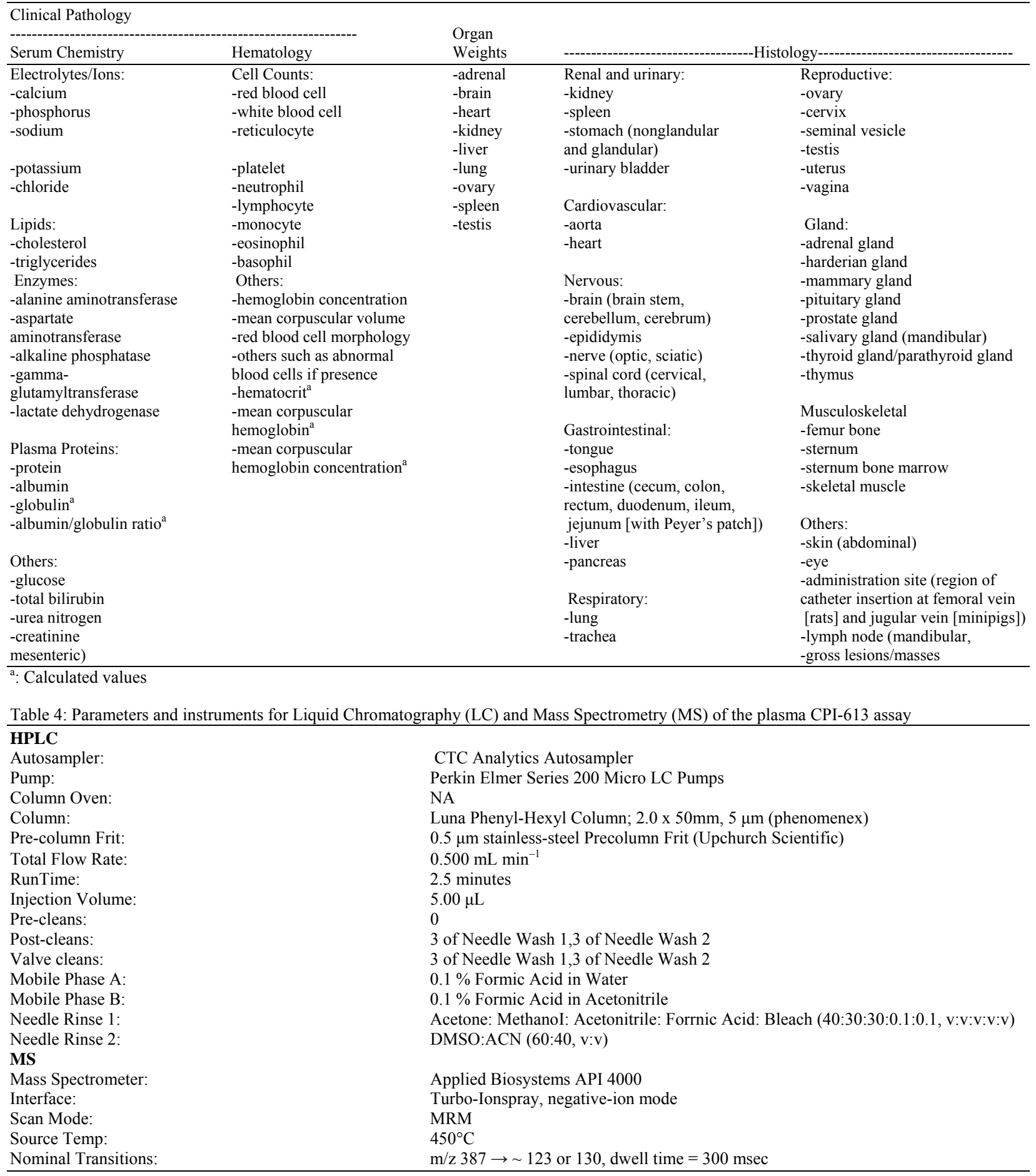

For full panel histopathology, the following organs and tissues were examined in situ, dissected free and fixed in $10 \%$ neutral buffered formalin (except for the testes which were fixed in Modified Davidson's fixative and the eyes with optic nerve which were fixed in Davidson's fixative): adrenal gland, administration site (region of catheter insertion at femoral vein (rats) or jugular vein (minipigs)), aorta, bone (femur), bone (sternum), bone marrow (sternum), brain (brain stem, cerebellum, cerebrum), cervix, epididymis, esophagus, 
eye, harderian gland, heart, intestine (cecum, colon, rectum, duodenum, ileum, jejunum (with Peyer's patch)), kidney, liver, lung, lymph node (mandibular, mesenteric), mammary gland, nerve (optic, sciatic), ovary, pancreas, pituitary gland, prostate gland, salivary gland (mandibular), seminal vesicle, skeletal muscle, skin (abdominal), spinal cord (cervical, lumbar, thoracic), spleen, stomach (nonglandular, glandular), testis, thymus, thyroid gland/parathyroid gland, tongue, trachea, urinary bladder, uterus, vagina and gross lesions/masses. Histopathology was performed on all tissues from all animals and all gross lesions. Slides were stained with hematoxylin and eosin and were microscopically evaluated.

Assessment and statistical analysis: The PK profile of each group was characterized by non-compartmental analysis of plasma concentrations of CPI-613 using validated computer software (WinNonlin, Version 3.2, Pharsight Corp., Mountain View, California, USA). The area under the "CPI-613 plasma concentrations vs time" curve (AUC) was calculated using the linear trapezoidal method with linear interpolation. Since the "CPI-613 plasma concentrations vs time" curve revealed that the elimination phase followed a 2compartment model with biphasic appearance (i.e., an initial distribution phase followed by a terminal elimination phase), onset of the terminal elimination phase was identified by the appearance of the inflection point between the initial distribution phase and the terminal elimination phase of the TK profile. The coefficient of determination of the line fitted to the terminal elimination phase was calculated. TK parameters describing the systemic exposure of the test article in the test system was estimated from observed plasma concentration values, the dosing regimen, the AUC and the terminal elimination phase rate constant for each group.

Statistical analysis was performed on body weights, body weight changes, food consumption, hematology, clinical chemistry parameters and organ weights. To determine the appropriate statistical test, each data set was subjected to a statistical decision tree. A minimum of three animals per sex per group per interval was required for statistical analysis. Treated groups of the same sex of all treatment groups were compared at all common time-points. The Bartlett's Test was used to compare overall variance among all groups. If the Bartlett's Test had a probability of $\mathrm{P}>0.05$, then a parametric distribution was assumed and a one-way Analysis Of Variance (ANOVA) was performed. A significant ANOVA result $(\mathrm{p} \leq 0.05)$ was followed by multiple comparisons using a post-hoc Dunnett's test to identify differences between absolute control and each treatment group. A non-significant ANOVA result $(p>0.05)$ indicated that no significant differences exist between the groups for the parameter under consideration. If the Bartlett's Test had a probability of $\mathrm{p} \leq 0.05$, then a non-parametric distribution was assumed and a Kruskal-Wallis test for independent groups was performed. A significant Kruskal-Wallis Test result $(\mathrm{p} \leq 0.05)$ was followed by multiple comparisons using a post-hoc Dunn's procedure to reveal differences between control(s) and each treatment group. A non-significant Kruskal-Wallis Test $(p>0.05)$ indicated that no significant differences exist between the groups for the parameter under consideration. For all tests and all quantitative parameters, a 95\% confidence level $(\mathrm{p} \leq 0.05)$ was the standard criterion for statistical significance.

\section{RESULTS}

There were no differences between males and females in their responses to CPI-613 treatment in both rats and minipigs in both experiments, with exceptions that are described below. Whenever there was a lack of differences between the two sexes, results from males and females were combined when evaluating the effects induced by CPI-613 or vehicle.

Analytical results of dosing solutions as a means to check the actual dose: In both experiments, analysis of the dosing solutions confirmed that the concentrations were as expected. Therefore, these results confirmed that the doses given to rats were as expected.

Mortality results: Experiment $\mathbf{A}$ in rats. The number of rats from Experiment A survived the course of the study in different treatment groups are shown in Fig. 1 and rats that died or euthanized moribund are individually listed in Table 5. Specifically, all rats in the D5W, vehicle and $25 \mathrm{mg} \mathrm{kg}^{-1}$ groups survived during the course of the study. Conversely, not all rats in the $30-35-\mathrm{mg} \mathrm{kg}^{-1}$ groups survived. Two of 48 rats $(4.2 \%)$ in the $30-\mathrm{mg} \mathrm{kg}^{-1}$ group were found dead on Days 1 or 2 of the study. Autopsy and histology findings showed that the cause of death in one rat was due to significant systemic inflammation and the cause of death in the other rat could not be determined. Four of 48 rats $(8.3 \%)$ in the $35-\mathrm{mg} \mathrm{kg}^{-1}$ group developed significant moribundity, which occurred on Day 2 in one rat, Day 8 in two rats and Day 20 in the remaining rat. These four rats were euthanized for humane reasons. The cause of moribundity in three of these four rats was due to significant systemic inflammation according to autopsy and histology findings, whereas the cause of moribundity in the remaining rat could not be determined. Therefore, these results showed that dose that induced $\sim 10 \%$ mortality $\left(\mathrm{LD}_{10}\right)$ is approximately $35 \mathrm{mg} \mathrm{kg}^{-1}$ in rats. 
Am. J. Pharm. \& Toxicol., 5 (4): 183-208, 2010

Table 5: Incidence of euthanized moribund and death in rats and minipigs from Experiments A and B, respectively

\begin{tabular}{|c|c|c|c|c|c|c|c|c|c|c|}
\hline \multirow[b]{2}{*}{ Experiments } & \multirow[b]{2}{*}{ Group } & \multirow[b]{2}{*}{ Dose $\left(\mathrm{mg} \mathrm{kg}^{-1}\right)$} & \multicolumn{2}{|c|}{ Number of animals } & \multicolumn{6}{|c|}{ Euthanized moribund or death } \\
\hline & & & Male & Female & Animal & Sex & $\begin{array}{l}\text { Study } \\
\text { Day }\end{array}$ & $\begin{array}{l}\text { Male } \\
(\%)\end{array}$ & $\begin{array}{l}\text { Female } \\
(\%)\end{array}$ & $\begin{array}{l}\text { Both sexes } \\
(\%)\end{array}$ \\
\hline \multirow{9}{*}{$\begin{array}{l}\text { Experiment } \mathrm{A} \\
\text { in rats }\end{array}$} & 1 & 0 (D5W) & 24 & 24 & . & . & . & & 0.00 & 0.00 \\
\hline & 2 & 0 (Vehicle) & 24 & 24 & . & . & . & 0.00 & 0.00 & 0.00 \\
\hline & 3 & 25 & 12 & 12 & & & & 0.00 & 0.00 & 0.00 \\
\hline & 4 & 30 & 24 & 24 & 1 & Female & 1 & $0.00 \%$ & $8.30 \%$ & $4.10 \%$ \\
\hline & & & & & 1 & Female & 2 & & & \\
\hline & 5 & 35 & 24 & 24 & 1 & Female & 2 & $12.50 \%$ & $4.20 \%$ & $8.30 \%$ \\
\hline & & & & & 1 & Male & 8 & & & \\
\hline & & & & & 1 & Male & 8 & & & \\
\hline & & & & & 1 & Male & 20 & & & \\
\hline \multirow{5}{*}{$\begin{array}{l}\text { Experiment B } \\
\text { in minipigs }\end{array}$} & 1 & $0(\mathrm{D} 5 \mathrm{~W})$ & 4 & 4 & . & . & . & 0.00 & 0.00 & 0.00 \\
\hline & 2 & 0 (Vehicle) & 4 & 4 & . & . & . & 0.00 & 0.00 & 0.00 \\
\hline & 3 & 45 & 4 & 4 & . & . & . & 0.00 & 0.00 & 0.00 \\
\hline & 4 & 50 & 4 & 4 & . & . & . & 0.00 & 0.00 & 0.00 \\
\hline & 5 & 55 & 4 & 4 & - & - & . & 0.00 & 0.00 & 0.00 \\
\hline
\end{tabular}

$\mathrm{D} 5 \mathrm{~W}=5 \%$ dextrose in water

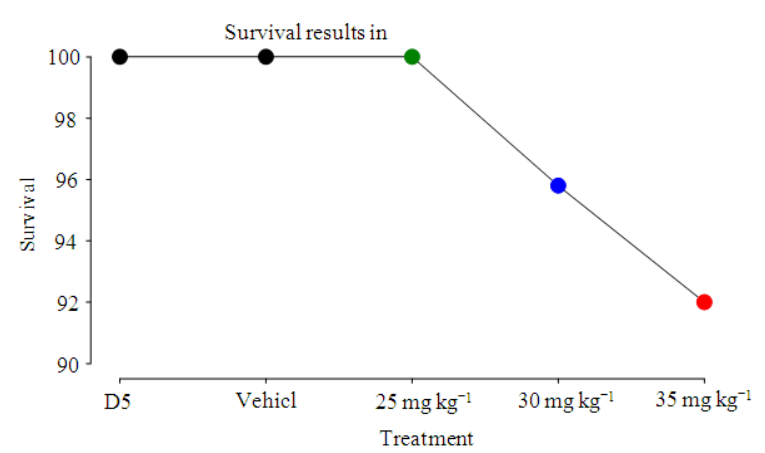

Fig. 1: Incidence of survival in different treatment groups of rats treated with $5 \%$ Dextrose in Water (D5W), vehicle, or CPI-613 at 25, 30 or $35 \mathrm{mg} \mathrm{kg}{ }^{-1}$, given $2 \mathrm{x}$ weekly for three consecutive weeks from Experiment A. Survival rats included those that did not die during the study, as well as those that did not develop significant moribund. There were 24 males and 24 females in all treatment groups, except for the $25 \mathrm{mg} \mathrm{kg}^{-1}$ group which had 12 males and 12 females. See Table 1 for specific treatment groups

Experiment $\mathbf{B}$ in minipigs. None of the minipigs from any of the five treatment groups died or euthanized moribund during the course of the study (Table 5). Therefore, the lethal dose for CPI-613 was $>55 \mathrm{mg} \mathrm{kg}^{-1}$ in minipigs.

Clinical observations: Experiment $\mathbf{A}$ in rats. The incidence and duration of clinical observations are listed in Table 6. In males, the following drug-related clinical signs were observed after administration of 30 and $35 \mathrm{mg} \mathrm{kg}{ }^{-1}$ of CPI-613: distended abdomen, hunched posture, impaired limb function, decreased activity, abnormal stool, decreased defecation, material in pan/bedding, necrosis at the site of administration, extended penis, abnormal testes and material around the nose. In females, the following drug-related clinical signs were observed after administration of $35 \mathrm{mg} \mathrm{kg}^{-1}$ of CPI-613: impaired limb function, necrosis at the site of administration and skin discoloration.

Experiment B in minipigs. The only apparent drugrelated clinical sign observed was vomiting that was transient and reversible and usually occurred on the days after administration of CPI-613 of all doses and the severity was dose-related (Table 6).

Body weight and food consumption: Experiment A in rats. There were no adverse effects on body weight (Table 7), body weight changes, or food consumption (Table 8) in rats treated with different doses of CPI-613 or vehicle, when compared to D5W-treated animals.

Experiment B in minipigs: There were no adverse effects on body weight (Table 7) or body weight changes in animals treated with various doses of CPI613 or vehicle, when compared to D5W-treated animals. There was rare occasional low food consumption in minipigs treated with CPI-613 at 45 and $55 \mathrm{mg} \mathrm{kg}{ }^{-1}$, which did not occur in other treatment groups (Table 9).

Clinical Pathology (chemistry and hematology): The clinical pathology data from males and females were analyzed separately due to significant differences between males and females in both species. 
Am. J. Pharm. \& Toxicol., 5 (4): 183-208, 2010

Table 6: CPI-613 related clinical observation during the studies from experiment A and B in rats and minipigs, respectively

\begin{tabular}{|c|c|c|c|c|c|c|}
\hline Types & Incidence & Group 1 & Group 2 & Group 3 & Group 4 & Group 5 \\
\hline \multicolumn{7}{|l|}{ Experiment $\mathrm{A}$ in rats-males } \\
\hline \multirow[t]{3}{*}{ Distended Abdomen } & \# of Observations & . & . & . & . & 1 \\
\hline & \# of Animals & . & . & . & . & 1 \\
\hline & Duration (Days from-to) & . & . & . & . & $8-8$ \\
\hline \multirow{3}{*}{ Hunched Posture } & \# of Observations & . & . & . & . & 2 \\
\hline & \# of Animals & . & . & . & . & 2 \\
\hline & Duration (Days from-to) & . & . & . & . & $8-8$ \\
\hline \multirow{3}{*}{ Impaired Limb Function } & \# of Observations & . & . & . & 3 & 6 \\
\hline & \# of Animals & . & . & . & 1 & 2 \\
\hline & Duration (Days from-to) & . & . & . & $14-16$ & $22-18$ \\
\hline \multirow[t]{3}{*}{ Activity Decreased } & \# of Observations & . & . & . & . & 1 \\
\hline & \# of Animals & . & . & . & . & 1 \\
\hline & Duration (Days from-to) & . & . & . & . & $8-8$ \\
\hline \multirow{3}{*}{ Abnormal Stool } & \# of Observations & . & . & . & 9 & 14 \\
\hline & \# of Animals & . & . & . & 4 & 2 \\
\hline & Duration (Days from-to) & . & . & . & $11-24$ & $11-23$ \\
\hline \multirow[t]{3}{*}{ Defecation Decreased } & \# of Observations & . & . & . & . & 5 \\
\hline & \# of Animals & . & . & . & . & 1 \\
\hline & Duration (Days from-to) & . & . & . & . & $7-3$ \\
\hline \multirow{3}{*}{ Material in Pan/Bedding } & \# of Observations & 2 & . & . & 1 & 5 \\
\hline & $\#$ of Animals & 1 & . & . & 1 & 5 \\
\hline & Duration (Days from-to) & 1112 & . & . & $4-4$ & $1-8$ \\
\hline \multirow{3}{*}{ Necrosis at Injection Site } & \# of Observations & . & . & . & . & 2 \\
\hline & \# of Animals & . & . & . & . & 2 \\
\hline & Duration (Days from-to) & . & . & & & $19-22$ \\
\hline \multirow[t]{3}{*}{ Abnormal Testes } & \# of Observations & . & . & 1 & 23 & . \\
\hline & \# of Animals & . & . & 1 & 3 & . \\
\hline & Duration (Days from-to) & . & . & $22-22$ & $16-29$ & \\
\hline \multirow[t]{3}{*}{ Penis Extended } & \# of Observations & . & . & . & 3 & 5 \\
\hline & \# of Animals & . & . & . & 1 & 1 \\
\hline & Duration (Days from-to) & . & - & & $22-24$ & $3-7$ \\
\hline \multirow[t]{3}{*}{ Material Around Nose } & \# of Observations & 11 & 17 & 14 & 23 & 25 \\
\hline & \# of Animals & 3 & 6 & 4 & 3 & 5 \\
\hline & Duration (Days from-to) & $15-22$ & $12-27$ & $12-22$ & $11-33$ & $3-26$ \\
\hline \multicolumn{7}{|l|}{ Experiment $A$ in rats-females } \\
\hline \multirow[t]{3}{*}{ Impaired Limb Function } & \# of Observations & . & . & . & 9 & 14 \\
\hline & \# of Animals & . & . & . & 4 & 4 \\
\hline & Duration (Days from-to) & . & . & . & $1-15$ & $1-22$ \\
\hline \multirow[t]{3}{*}{ Necrosis at site of administration } & \# of Observations & . & . & . & . & 14 \\
\hline & \# of Animals & . & . & . & . & 1 \\
\hline & Duration (Days from-to) & . & . & . & . & $20-33$ \\
\hline \multirow[t]{3}{*}{ Skin Discolored } & \# of Observations & . & . & . & . & 9 \\
\hline & \# of Animals & . & . & . & . & 3 \\
\hline & Duration (Days from-to) & . & . & . & . & $20-33$ \\
\hline Experiment B in Minipigs-Male & & & & & & \\
\hline Vomitus & \# of Observations & . & . & . & 3 & 8 \\
\hline & \# of Animals & . & . & . & 1 & 4 \\
\hline & Duration (Days from-to) & . & . & . & $1-15$ & $1-19$ \\
\hline Vomitus, Discolor & \# of Observations & . & . & . & 2 & 4 \\
\hline & \# of Animals & . & . & . & 1 & 2 \\
\hline & Duration (Days from-to) & . & . & . & $1-4$ & $1-19$ \\
\hline Experiment B in Minipigs-Fema & & & & & & \\
\hline Vomitus & \# of Observations & . & . & 3 & 3 & 3 \\
\hline & \# of Animals & . & . & 2 & 2 & 2 \\
\hline & Duration (Days from-to) & . & . & $4-15$ & $1-5$ & $4-19$ \\
\hline Vomitus, Discolor & \# of Observations & . & . & 3 & 1 & 3 \\
\hline & \# of Animals & . & . & 2 & 1 & 2 \\
\hline & Duration (Days from-to) & . & . & $4-15$ & 4 & $4-15$ \\
\hline
\end{tabular}

Experiment A in rats: There were no significant changes in any of the clinical pathology parameters in male or female rats based on statistical analyses and comparison to historical control data, with the exception of reticulocytes and GGT. For reticulocytes, CPI-613 at 30-35 mg kg-1 increased both the $\%$ and absolute values after the 6 th or last dose, when compared to concurrent values from D5W and vehicle treatments, in male rats (Fig. 2). 
Am. J. Pharm. \& Toxicol., 5 (4): 183-208, 2010

Table 7: Body weights during the studies in rats (gm) and minipigs ( $\mathrm{kg}$ ) from Experiments A and B, respectively

\begin{tabular}{|c|c|c|c|c|c|c|c|c|c|c|c|}
\hline \multirow[b]{2}{*}{ Experiments } & \multirow[b]{2}{*}{ Sex } & \multirow[b]{2}{*}{ Group } & \multirow[b]{2}{*}{ Values } & \multicolumn{8}{|c|}{ Study days } \\
\hline & & & & Day 1 & $\begin{array}{l}\text { Day } \\
4-5\end{array}$ & Day 8 & $\begin{array}{l}\text { Day } \\
11-12\end{array}$ & Day 15 & $\begin{array}{l}\text { Day } \\
18-19\end{array}$ & $\begin{array}{l}\text { Day } \\
21-22\end{array}$ & Day 32 \\
\hline \multirow{30}{*}{$\begin{array}{l}\text { Experiment A } \\
\text { in Rats }\end{array}$} & \multirow[t]{15}{*}{ Male } & \multirow[t]{3}{*}{1} & Mean & 358 & 366 & 377 & 358 & 389 & 396 & 388 & 417 \\
\hline & & & SD & 16 & 16 & 19 & 21 & 20 & 20 & 28 & 20 \\
\hline & & & $\mathrm{N}$ & 24 & 24 & 24 & 24 & 24 & 24 & 24 & 12 \\
\hline & & \multirow[t]{3}{*}{2} & Mean & 356 & 368 & 378 & 359 & 389 & 401 & 386 & 425 \\
\hline & & & SD & 16 & 15 & 14 & 13 & 13 & 14 & 16 & 13 \\
\hline & & & $\mathrm{N}$ & 24 & 24 & 24 & 24 & 24 & 24 & 24 & 12 \\
\hline & & \multirow[t]{3}{*}{3} & Mean & 346 & 355 & 367 & 342 & 378 & 388 & 375 & -- \\
\hline & & & $\mathrm{SD}$ & 17 & 15 & 17 & 16 & 21 & 21 & 24 & -- \\
\hline & & & $\mathrm{N}$ & 12 & 12 & 12 & 12 & 12 & 12 & 12 & -- \\
\hline & & \multirow[t]{3}{*}{4} & Mean & 363 & 369 & 375 & 355 & 381 & 391 & 377 & 418 \\
\hline & & & SD & 19 & 22 & 22 & 20 & 23 & 22 & 20 & 18 \\
\hline & & & $\mathrm{N}$ & 24 & 24 & 24 & 24 & 24 & 24 & 24 & 12 \\
\hline & & \multirow[t]{3}{*}{5} & Mean & 364 & 368 & 371 & 356 & 386 & 396 & 370 & 431 \\
\hline & & & SD & 22 & 24 & 30 & 27 & 29 & 29 & 34 & 23 \\
\hline & & & $\mathrm{N}$ & 24 & 24 & 24 & 22 & 22 & 22 & 21 & 11 \\
\hline & Female & 1 & Mean & 249 & 251 & 256 & 252 & 263 & 268 & 259 & 282 \\
\hline & & & SD & 16 & 11 & 13 & 14 & 15 & 16 & 13 & 14 \\
\hline & & & $\mathrm{N}$ & 24 & 24 & 24 & 24 & 24 & 24 & 24 & 12 \\
\hline & & 2 & Mean & 251 & 252 & 255 & 255 & 266 & 271 & 266 & 284 \\
\hline & & & SD & 14 & 14 & 14 & 12 & 14 & 14 & 14 & 17 \\
\hline & & & $\mathrm{N}$ & 24 & 24 & 24 & 24 & 24 & 24 & 24 & 12 \\
\hline & & 3 & Mean & 248 & 250 & 254 & 240 & 262 & 263 & 262 & -- \\
\hline & & & SD & 13 & 12 & 11 & 11 & 10 & 12 & 11 & -- \\
\hline & & & $\mathrm{N}$ & 12 & 12 & 12 & 12 & 12 & 12 & 12 & -- \\
\hline & & 4 & Mean & 255 & 255 & 258 & 255 & 267 & 271 & 264 & 283 \\
\hline & & & SD & 15 & 13 & 13 & 14 & 13 & 15 & 16 & 11 \\
\hline & & & $\mathrm{N}$ & 24 & 24 & 24 & 24 & 24 & 24 & 24 & 12 \\
\hline & & 5 & Mean & 247 & 251 & 254 & 255 & 265 & 270 & 268 & 280 \\
\hline & & & SD & 15 & 15 & 15 & 13 & 17 & 17 & 19 & 16 \\
\hline & & & $\mathrm{N}$ & 24 & 24 & 24 & 24 & 24 & 24 & 24 & 12 \\
\hline Experiment B & Male & 1 & Mean & 25 & 26 & 27 & 28 & 28 & 29 & 30 & -- \\
\hline in minipigs & & & SD & 3 & 3 & 2 & 3 & 3 & 4 & 4 & -- \\
\hline & & & $\mathrm{N}$ & 4 & 4 & 4 & 4 & 4 & 4 & 4 & -- \\
\hline & & 2 & Mean & 24 & 25 & 26 & 26 & 27 & 28 & 29 & -- \\
\hline & & & SD & 1 & 2 & 2 & 2 & 1 & 1 & 1 & -- \\
\hline & & & $\mathrm{N}$ & 4 & 4 & 4 & 4 & 4 & 4 & 4 & -- \\
\hline & & 3 & Mean & 26 & 28 & 29 & 29 & 30 & 30 & 33 & -- \\
\hline & & & SD & 2 & 2 & 2 & 2 & 1 & 2 & 2 & -- \\
\hline & & & $\mathrm{N}$ & 4 & 4 & 4 & 4 & 4 & 4 & 4 & -- \\
\hline & & 4 & Mean & 25 & 26 & 26 & 27 & 26 & 27 & 28 & -- \\
\hline & & & SD & 1 & 2 & 2 & 2 & 2 & 2 & 1 & -- \\
\hline & & & $\mathrm{N}$ & 4 & 4 & 4 & 4 & 4 & 4 & 4 & -- \\
\hline & & 5 & Mean & 26 & 27 & 27 & 28 & 28 & 28 & 29 & -- \\
\hline & & & SD & 3 & 3 & 3 & 4 & 4 & 5 & 4 & -- \\
\hline & & & $\mathrm{N}$ & 4 & 4 & 4 & 4 & 4 & 4 & 4 & -- \\
\hline & Female & 1 & Mean & 21 & 22 & 23 & 23 & 24 & 24 & 25 & -- \\
\hline & & & SD & 3 & 3 & 3 & 3 & 3 & 4 & 3 & -- \\
\hline & & & $\mathrm{N}$ & 4 & 4 & 4 & 4 & 4 & 4 & 4 & -- \\
\hline & & 2 & Mean & 22 & 22 & 23 & 23 & 24 & 25 & 25 & -- \\
\hline & & & SD & 2 & 2 & 2 & 2 & 2 & 3 & 2 & -- \\
\hline & & & $\mathrm{N}$ & 4 & 4 & 4 & 4 & 4 & 4 & 4 & -- \\
\hline & & 3 & Mean & 21 & 22 & 23 & 23 & 24 & 24 & 26 & -- \\
\hline & & & SD & 4 & 4 & 4 & 4 & 5 & 4 & 5 & -- \\
\hline & & & $\mathrm{N}$ & 4 & 4 & 4 & 4 & 4 & 4 & 4 & -- \\
\hline & & 4 & Mean & 21 & 22 & 23 & 24 & 24 & 25 & 26 & -- \\
\hline & & & SD & 3 & 3 & 3 & 3 & 3 & 4 & 3 & -- \\
\hline & & & $\mathrm{N}$ & 4 & 4 & 4 & 4 & 4 & 4 & 4 & -- \\
\hline & & 5 & Mean & 23 & 24 & 24 & 25 & 26 & 27 & 27 & -- \\
\hline & & & SD & 3 & 4 & 4 & 3 & 3 & 4 & 4 & -- \\
\hline & & & $\mathrm{N}$ & 4 & 4 & 4 & 4 & 4 & 4 & 4 & -- \\
\hline
\end{tabular}


Am. J. Pharm. \& Toxicol., 5 (4): 183-208, 2010

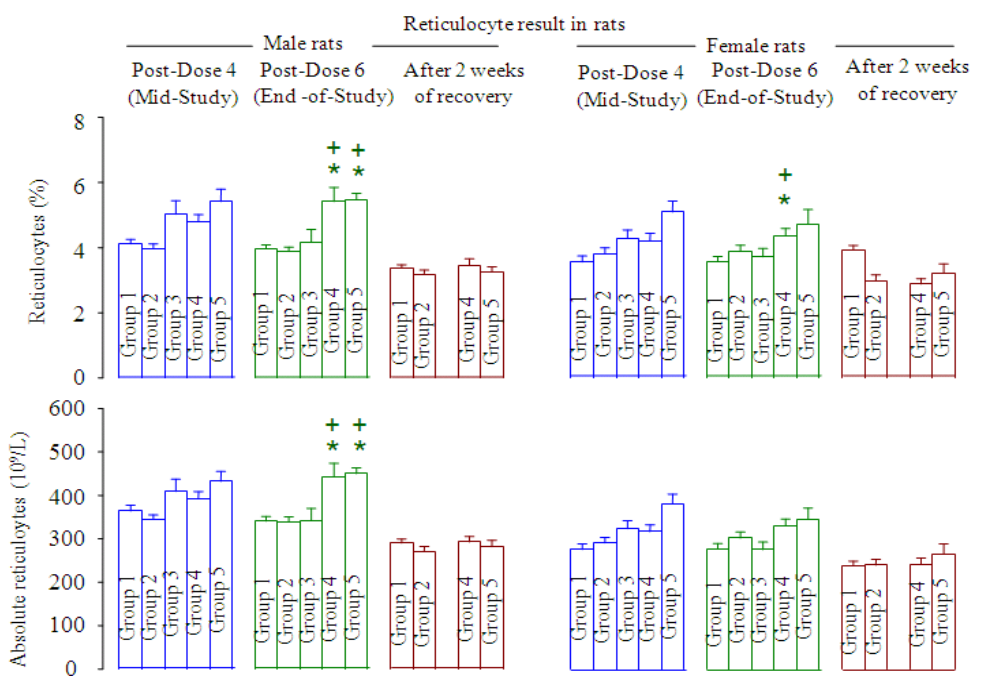

Fig. 2: Reticulocytes (\% and absolute) in male and female rats treated with 5\% Dextrose in Water (D5W) in Group 1, vehicle in Group 2 and CPI-613 at 25, 30 or $35 \mathrm{mg} \mathrm{kg}^{-1}$ in Groups 3, 4 and 5, respectively, given 2x weekly for three consecutive weeks from Experiment A. There were 24 males and 24 females in all treatment groups, except for the $25-\mathrm{mg} / \mathrm{kg}$ group which had 12 males and 12 females. In all treatment groups other than the 25 $\mathrm{mg} \mathrm{kg}{ }^{-1}$ groups, one-half of the animals were euthanized on day 22, whereas the other half of the animals were euthanized on day 33. For the $25 \mathrm{mg} \mathrm{kg}^{-1}$ group, all animals were euthanized on day 22. See Table 1 for specific treatment groups. Results are presented as mean \pm Standard Error of the Mean (SEM). $+=$ significantly higher than the D5W group and * = significantly higher than the vehicle group, at $\mathrm{p} \leq 0.05$ level

Table 8: Food consumption (g/day) during the studies in rats from Experiment A.

\begin{tabular}{|c|c|c|c|c|c|c|c|}
\hline \multirow[b]{2}{*}{ Sex } & \multirow[b]{2}{*}{ Group } & \multirow[b]{2}{*}{ Values } & \multicolumn{5}{|c|}{ Food consumption } \\
\hline & & & Days $1-8$ & Days $8-15$ & Days $15-22$ & Days 22-29 & Days 29-32 \\
\hline \multirow[t]{15}{*}{ Male } & 1 & Mean & 29 & 26 & 26.0 & 27 & 25 \\
\hline & & SD & 3 & 2 & 1.5 & 1 & 1 \\
\hline & & $\mathrm{N}$ & 24 & 23 & 23.0 & 12 & 12 \\
\hline & 2 & Mean & 29 & 27 & 27.0 & 27 & 26 \\
\hline & & SD & 2 & 2 & 2.5 & 1 & 2 \\
\hline & & $\mathrm{N}$ & 24 & $23^{\mathrm{a}}$ & $23.0^{\mathrm{a}}$ & 12 & 12 \\
\hline & 3 & Mean & 29 & 27 & 27.0 & r. & . \\
\hline & & SD & 3 & 3 & 2.0 & . & . \\
\hline & & $\mathrm{N}$ & 12 & 12 & 12.0 & & . \\
\hline & 4 & Mean & 28 & 27 & 27.0 & 29 & 24 \\
\hline & & SD & 2 & 3 & 4.5 & 4 & 5 \\
\hline & & $\mathrm{N}$ & 24 & 24 & 24.0 & 12 & 12 \\
\hline & 5 & Mean & 26 & 27 & 26.0 & 29 & 26 \\
\hline & & SD & 5 & 3 & 3.0 & 2 & 2 \\
\hline & & $\mathrm{N}$ & 24 & $22^{\mathrm{a}}$ & $21.0^{\mathrm{a}}$ & $11^{\mathrm{a}}$ & $11^{\mathrm{a}}$ \\
\hline \multirow[t]{15}{*}{ Female } & 1 & Mean & 23 & 22 & 21.0 & 25 & 20 \\
\hline & & SD & 1 & 2 & 2.0 & 2 & 2 \\
\hline & & $\mathrm{N}$ & 23 & 24 & 24.0 & 12 & 12 \\
\hline & 2 & Mean & 22 & 23 & 21.5 & 25 & 19 \\
\hline & & SD & 4 & 1 & 2.5 & 2 & 3 \\
\hline & & $\mathrm{N}$ & 23 & 24 & 24.0 & 12 & 12 \\
\hline & 3 & Mean & 24 & 23 & 23.0 & r. & . \\
\hline & & SD & 1 & 1 & 2.0 & 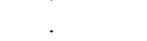 & . \\
\hline & & $\mathrm{N}$ & 12 & 12 & 12.0 & & . \\
\hline & 4 & Mean & 24 & 23 & $23.0 \#$ & 26 & 19 \\
\hline & & SD & 5 & 1 & 1.5 & 1 & 1 \\
\hline & & $\mathrm{N}$ & $23^{\mathrm{a}}$ & $23^{\mathrm{a}}$ & 24.0 & 12 & 12 \\
\hline & 5 & Mean & 23 & 23 & 22.5 & 27 & 19 \\
\hline & & SD & 2 & 3 & 2.0 & 2 & 2 \\
\hline & & $\mathrm{N}$ & $22^{\mathrm{a}}$ & $22^{\mathrm{a}}$ & $22.0^{\mathrm{a}}$ & 12 & 12 \\
\hline
\end{tabular}


Am. J. Pharm. \& Toxicol., 5 (4): 183-208, 2010
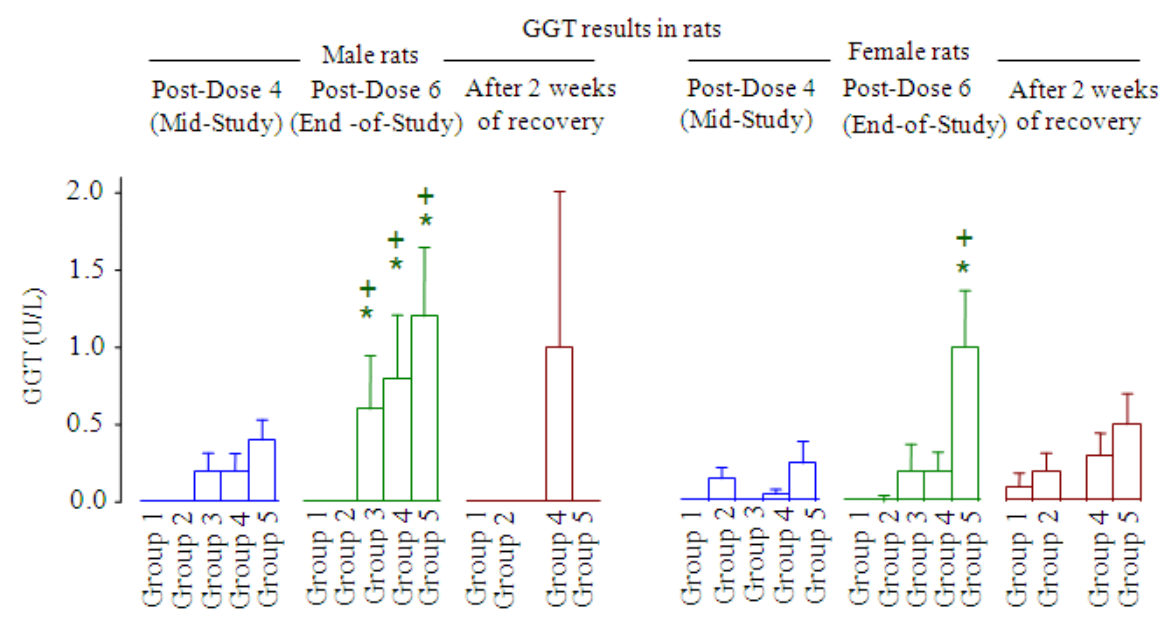

Fig. 3: Gamma-Glutamyltransferase (GGT) in male and female rats treated with 5\% Dextrose in Water (D5W) in Group 1, vehicle in Group 2 and CPI-613 at 25, 30 or $35 \mathrm{mg} \mathrm{kg}^{-1}$ in Groups 3, 4 and 5, respectively, given 2x weekly for three consecutive weeks from Experiment A. There were 24 males and 24 females in all treatment groups, except for the $25 \mathrm{mg} \mathrm{kg}^{-1}$ group which had 12 males and 12 females. In all treatment groups other than the $25 \mathrm{mg} \mathrm{kg}^{-1}$ groups, one-half of the animals were euthanized on day 22, whereas the other half of the animals were euthanized on day 33. For the $25 \mathrm{mg} \mathrm{kg}^{-1}$ group, all animals were euthanized on day 22. See Table 1 for specific treatment groups. Results are presented as mean \pm Standard Error of the Mean (SEM). +: Significantly higher than the D5W group and *: Significantly higher than the vehicle group, at $\mathrm{p} \leq 0.05$ level

Table 9: Food consumption pattern during the studies in minipigs from experiment $\mathrm{B}$

\begin{tabular}{|c|c|c|c|c|c|c|c|}
\hline \multirow{2}{*}{$\begin{array}{l}\text { Sex } \\
\text { Male }\end{array}$} & \multicolumn{2}{|c|}{----------Food consumption---------- } & \multirow{2}{*}{ Group 1} & \multirow{2}{*}{$\begin{array}{l}\text { Group } 2 \\
\end{array}$} & \multirow{2}{*}{$\begin{array}{l}\text { Group } 3 \\
\end{array}$} & \multirow{2}{*}{ Group 4} & \multirow{2}{*}{$\begin{array}{l}\text { Group } 5 \\
2\end{array}$} \\
\hline & Scant $^{\mathrm{a}}$ & \# of Observations & & & & & \\
\hline & & \# of Animals & & . & . & . & 1 \\
\hline & & Days & . & . & . & . & 6,17 \\
\hline & Low $^{a}$ & \# of Observations & . & . & 3 & . & 1 \\
\hline & & \# of Animals & . & . & 2 & . & 1 \\
\hline & & Days Observed & . & . & $2,20,21$ & . & 18 \\
\hline \multirow[t]{6}{*}{ Females } & Scant $^{\mathrm{a}}$ & \# of Observations & . & . & . & . & . \\
\hline & & \# of Animals & . & . & . & . & . \\
\hline & & Days Observed & . & . & . & . & . \\
\hline & Low $^{\mathrm{a}}$ & \# of Observations & . & . & 1 & . & . \\
\hline & & \# of Animals & . & . & 1 & . & . \\
\hline & & Days Observed & . & . & 20 & . & . \\
\hline
\end{tabular}

${ }^{a}$ : Normal: No food remaining; Low: Up to half of the previous food allocation remaining; Scant: More than half of the previous food allocation remaining

CPI-613 also increased the \% values of reticulocytes after the 6 th dose, when compared to concurrent values from D5W and vehicle treatments, in female rats. At the end of the recovery period (i.e., two weeks after the last dose of CPI-613), the reticulocyte values in the CPI-613 treated groups were no longer higher than the D5W or vehicle groups, suggesting that the CPI-613induced increases in reticulocytes were reversible upon termination of CPI-613 treatment.

For GGT, CPI-613 at all three doses increased GGT values when compared to D5W and vehicle after the 6th doses (i.e., during mid-study and end-of-study assessments, respectively) and the magnitude of increases were in a dose-related manner in male rats (Fig. 3). In female rats, CPI-613 at the highest doses increased GGT values when compared to D5W and vehicle after the 6th dose. The mean GGT values in the $35-\mathrm{mg} \mathrm{kg}^{-1}$ group were lower two weeks after the study when compared to those at the end of the study in both male and female rats, suggesting that the increases in GGT values might be reversible. Interestingly, vehicle also slightly increased GGT values, when compared to D5W, after the 4th dose and after the 2-week recovery period in female rats. Therefore, vehicle might be partially responsible for the increased GGT induced by CPI-613.

Experiment $\mathbf{B}$ in minipigs: There were no toxicologically or biologically significant changes in hematology in males or females during the study. CPI613 at all doses tested did not cause toxicologically or biologically significant changes in any clinical chemistry parameters during the study. 
ECG: ECG was assessed in minipigs in Experiment B. There were no changes of any biological or toxicological significance associated with D5W, vehicle or different doses of CPI-613. Specifically, there were no toxicologically significant effects on heart rate, RR interval, PR interval, QRS duration, QT interval, or QTc. No treatment-related arrhythmias were detected.

Gross pathology: Experiment $A$ in rats. Gross pathology findings are listed in Table 10. Nodules, masses, or crusts at the injection site, inguinal skin and subcutaneous tissues near the port, as well as histological evidence of inflammation, were observed in CPI-613 treated rats and the severity and frequency were dose-related. Gross lesions tended to be more frequent in males than female rats. The gross inflammatory process at the injection site extended to the reproductive organs (prostate, epididymis, seminal vesicle or testis) of Group 5 male rats (treated with 35 $\mathrm{mg} \mathrm{kg}{ }^{-1}$ of CPI-613) and a single Group 3 male rat (treated with $25 \mathrm{mg} \mathrm{kg}{ }^{-1}$ CPI-613). Many of these findings were consistent with the clinical observation of the current study.

In Recovery rats (rats that were assessed after a 2week recovery period), there was a significant reduction in the incidence of gross findings of skin crust or subcutaneous nodules at or near the injection site or port in mid-and high-dose male rats and high-dose female rats and a pronounced reduction in findings of nodules and masses of male reproductive organs of high-dose males. These results suggested that the gross pathological findings were reversible upon termination of treatment with CPI-613.

Experiment $\mathbf{B}$ in minipigs. CPI-613-related gross lesions were observed and they included nodules, masses, crusts or fluid at the administration site and subcutaneous tissue near the port (Table 11). These gross findings most often correlated with ulcerative and/or chronic-active inflammation. The incidences were not dose-dependent.

Organ weights: Experiments $A$ and $B$ in rats and minipigs, respectively. In rats, there were no statistically significant differences in absolute organ weight values or changes in organ weights from baseline, with the exception of the higher spleen weights observed at the end of the treatment period in CPI-613 treated rats when compared with D5W rats $(0.833 \pm 0.022 \mathrm{~g}$ Vs. $1.192 \pm 0.103 \mathrm{~g})$. This may be associated with the hematopoietic cell proliferation of the spleen possibly secondary to the inflammatory effects of CPI-613. In minipigs, there were no abnormal effects of CPI-613 on organ weights.
Histopathology: Experiment A in rats. The results from histopathology performed at the end of the study on day 22 as well as those performed at the end of the recovery period on day 33 are shown in Table 12. The histopathology results showed a dose-dependent exaggeration in incidence and severity of granulomatous or acute, chronic or chronic active inflammation at the administration site (inguinal vein), skin and subcutaneous tissue near the port and inguinal skin and subcutaneous tissue near the inguinal vein were observed. Lymphoid hyperplasia in drainage lymph nodes (iliac and mediastinal), hematopoietic cell proliferation of the spleen and sternal bone marrow hyperplasia were considered secondary to inflammation initiated at the administration site or port, rather than primary effects of CPI-613 due to a lack of other effects such as a lack of increase in blood cell counts.

According to histopathology performed after a 2week recovery period, there was a reduction in the incidence and severity of moderate or marked inflammation at or adjacent to the administration site or port observed in mid-and high-dose males and females. The most notable difference was a reduction in the incidence of inflammation of the abdominal organs that was considered an extension of the inflammatory reaction initiated at the administration site, including inflammation and spermatic granuloma of the epididymis, inflammation of the seminal vesicle and testes in highdose males. Once again, these results suggested that the histopathlogical findings were reversible.

Experiment $\mathbf{B}$ in minipigs: The results from histopathology performed at the end of the study on day 22 are shown in Table 13. These results showed that thromboses (unilateral or bilateral) surrounding the catheter and involving the vein wall were noted in all CPI-613 groups of both sexes. A significant, chronicallyactive inflammation involving the vein wall and perivascular tissue was noted in several animals, but there was no relationship to the dose. Skin lesions in areas noted related to the administration site (primarily head and back) were relatively common and consisted primarily of ulcerative inflammation and/or hyperkeratosis. There was no dose relationship. Chronically-active inflammation and an abscess were noted in the lung of one Group 5 male (treated with 55 $\mathrm{mg} \mathrm{kg}^{-1}$ of CPI-613), but it is believed that the inflammation was closely related to inflammation at the administration site. Marked bone marrow hyperplasia was also noted in this animal. Moderate lymphoid hyperplasia of the Bronchiole-Associated Lymphoid Tissue (BALT) was noted in two Group 5 females (both treated with $55 \mathrm{mg} \mathrm{kg}^{-1}$ of CPI-613), but not in any other animals. 
Am. J. Pharm. \& Toxicol., 5 (4): 183-208, 2010

Table 10: Findings from full gross necropsy in rats from Experiment A. Full panel necropsy included examination of the carcass and musculoskeletal system, all external surfaces and orifices, cranial cavity and external surface of the brain, thoracic, abdominal, and pelvic cavities with their associated organs and tissues

\begin{tabular}{|c|c|c|c|c|}
\hline Group & Sex & Day Performed & Rats & Observations \\
\hline \multirow[t]{9}{*}{1} & \multirow[t]{5}{*}{ M } & Day 22 & 429 & EYE: Discoloration, pale, left, TGL-small \\
\hline & & \multirow[t]{3}{*}{ (12 were examined) } & 435 & THYMUS: Discoloration, mottled, TGL-small \\
\hline & & & 439 & SKIN-back: Crust, red, TGL- $5 \times 10 \mathrm{~mm}$, above port site \\
\hline & & & 441 & EYE-cornea: Crust, dark, left, TGL-small \\
\hline & & $\begin{array}{l}\text { Day } 33 \\
\text { (12 were examined) }\end{array}$ & 455 & SKIN-forefoot: Thick, left, TGL-small \\
\hline & \multirow[t]{4}{*}{$\mathrm{F}$} & Day 22 & 426 & SKIN-back: Crust, red TGL: $3 \times 4 \mathrm{~mm}$, at port site \\
\hline & & (12 were examined) & 432 & SKIN-back: Crust, dark TGL: $5 \times 11 \mathrm{~mm}$ \\
\hline & & & 440 & LIVER-medial lobe: Nodule, $\tan$ TGL- $7 \times 7 \mathrm{~mm}$ \\
\hline & & $\begin{array}{l}\text { Day } 33 \\
\text { (12 were examined) }\end{array}$ & 468 & $\begin{array}{l}\text { SKIN-subcutaneous: Nodule, back, dark TGL-15×15 mm, } \\
\text { over port site, consistent with a hematoma }\end{array}$ \\
\hline \multirow[t]{15}{*}{2} & \multirow[t]{6}{*}{ M } & Day 22 & 473 & EPIDIDYMIS: Missing, left. \\
\hline & & (12 were examined) & & TESTIS: Small, left, TGL-small \\
\hline & & & 491 & $\begin{array}{l}\text { SKIN-subcutaneous: Nodule, inguinal, mottled, TGL- } \\
12 \times 12 \mathrm{~mm} \text {, left side, near the administration site }\end{array}$ \\
\hline & & Day 33 & 495 & SKIN-back: Crust, brown, TGL-10×10 mm, over port site \\
\hline & & (12 were examined) & 513 & LYMPH NODE-mandibular: Discoloration, dark, right, TGL-small \\
\hline & & & 517 & LIVER-medial lobe: Adhesion was to diaphragm, TGL-small \\
\hline & \multirow[t]{9}{*}{$\mathrm{F}$} & Day 22 & 472 & SKIN-back: Crust, brown TGL-small, on port site \\
\hline & & (12 were examined) & 478 & UTERUS: Enlarged, bilateral TGL \\
\hline & & & 484 & SKIN-subcutaneous: Nodule, back, green TGL: $10 \times 20 \mathrm{~mm}$, at port site \\
\hline & & & 486 & LYMPH NODE-iliac: Enlarged, bilateral TGL-small \\
\hline & & $\begin{array}{l}\text { Day } 33 \\
\text { (12 were examined) }\end{array}$ & 496 & $\begin{array}{l}\text { SKIN-subcutaneous: Nodule, inguinal, green TGL-15x10mm, near } \\
\text { administration site, left }\end{array}$ \\
\hline & & & 502 & $\begin{array}{l}\text { KIDNEY-capsule: Focus, white, left, multiple TGL- } 3 \times 1 \mathrm{~mm} \text {, } \\
\text { LYMPH NODE-mandibular: Discoloration, mottled, left TGL-small } \\
\text { SKIN-back: Crust, brown TGL- } 7 \times 9 \mathrm{~mm} \text {, over port site }\end{array}$ \\
\hline & & & 506 & $\begin{array}{l}\text { SKIN-back: Laceration TGL- } 3 \times 6 \mathrm{~mm} \text {, suture material present on one } \\
\text { side of lesion }\end{array}$ \\
\hline & & & 508 & $\begin{array}{l}\text { SKIN-subcutaneous: Nodule, inguinal, green TGL-5 } \times 7 \mathrm{~mm} \text {, near } \\
\text { administration site, left }\end{array}$ \\
\hline & & & 514 & SKIN-inguinal: Crust, brown, left TGL- $3 \times 3 \mathrm{~mm}$, located near staples \\
\hline \multirow[t]{10}{*}{3} & \multirow[t]{5}{*}{$\mathrm{M}$} & \multirow[t]{5}{*}{$\begin{array}{l}\text { Day } 22 \\
\text { (12 were examined) }\end{array}$} & 519 & $\begin{array}{l}\text { SKIN-inguinal: Nodule, subcutaneous, tan, TGL-10×15 mm, } \\
\text { under staples }\end{array}$ \\
\hline & & & 537 & THYMUS: Focus, dark, multiple, TGL- $1 \times 2 \mathrm{~mm}$ \\
\hline & & & 539 & ADMINISTRATION SITE: Nodule, tan, TGL-10×15 mm \\
\hline & & & & $\begin{array}{l}\text { EPIDIDYMIS: Mass, tan, left, TGL- } 15 \times 25 \mathrm{~mm} \text {, adhered to abdominal wall } \\
\text { LYMPH NODE-mediastinal: Enlarged, red, TGL-small } \\
\text { TESTIS: Adhesion to scrotum, left TGL-small }\end{array}$ \\
\hline & & & 541 & SKIN-back: Crust, red, TGL- $5 \times 12 \mathrm{~mm}$, over port \\
\hline & \multirow[t]{5}{*}{$\mathrm{F}$} & Day 22 & 520 & THYMUS: Discoloration, mottled TGL \\
\hline & & (12 were examined) & 526 & $\begin{array}{l}\text { SKIN-inguinal: Nodule, subcutaneous, tan TGL-12×15 mm, near } \\
\text { administration site, left }\end{array}$ \\
\hline & & & 530 & SKELETAL MUSCLE-back: Thick, right TGL-small, psoas major muscle \\
\hline & & & 532 & SKIN-subcutaneous: Fluid, pink: fluid around port site \\
\hline & & & 536 & $\begin{array}{l}\text { SKIN-subcutaneous: Nodule, hindlimb, dark, left TGL-3 } \times 3 \mathrm{~mm} \text {, near } \\
\text { administration site }\end{array}$ \\
\hline \multirow[t]{11}{*}{4} & \multirow[t]{11}{*}{ M } & \multirow[t]{11}{*}{$\begin{array}{l}\text { Day } 22 \\
\text { (12 were examined) }\end{array}$} & 547 & $\begin{array}{l}\text { LIVER-lateral lobe: Adhesion, to lumbar musculature, right, TGL-small } \\
\text { SKIN-inguinal: Nodule, subcutaneous, green, TGL-13×14 mm, near } \\
\text { administration site, left }\end{array}$ \\
\hline & & & 551 & LYMPH NODE-iliac: Mass, left, TGL-20×20 mm \\
\hline & & & 553 & $\begin{array}{l}\text { SKIN-inguinal: Nodule, subcutaneous, tan, TGL- } 20 \times 20 \mathrm{~mm} \text {, left, near } \\
\text { administration site }\end{array}$ \\
\hline & & & 557 & $\begin{array}{l}\text { SKIN-inguinal: Nodule, subcutaneous, tan, TGL- } 12 \times 22 \mathrm{~mm} \text {, left, near } \\
\text { administration site }\end{array}$ \\
\hline & & & 559 & SKELETAL MUSCLE-hindlimb: Nodule, left, TGL-10×15 mm \\
\hline & & & 561 & LYMPH NODE-iliac: Discoloration, dark, left, TGL-small \\
\hline & & & & LYMPH NODE-renal: Discoloration, dark, left, TGL-small \\
\hline & & & 563 & LYMPH NODE-iliac: Enlarged, left, TGL-small \\
\hline & & & & $\begin{array}{l}\text { SKIN-inguinal: Nodule, subcutaneous, green, TGL-10×15 mm, left, near } \\
\text { administration site }\end{array}$ \\
\hline & & & 565 & LYMPH NODE-mediastinal: Enlarged, TGL-small \\
\hline & & & & $\begin{array}{l}\text { SKIN-inguinal: Mass, subcutaneous, tan, TGL-30 } \times 15 \mathrm{~mm} \text {, left side, near } \\
\text { administration site }\end{array}$ \\
\hline
\end{tabular}


Am. J. Pharm. \& Toxicol., 5 (4): 183-208, 2010

Table 10: Continue

$\begin{array}{lc}\begin{array}{l}\text { Day } 33 \\ \text { (12 were examined) }\end{array} & 571 \\ & 579 \\ & \\ & 581 \\ & 585 \\ & 587\end{array}$

581

F Day 22

(12 were examined)

544

546

550

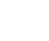

556

566

1120

Day 33

(12 were examined)

568

574

578

586

$1116 \mathrm{a}$

591

593

595

597

$599 b$

$601 \mathrm{~b}$
SKIN-subcutaneous: Nodule, inguinal, green, TGL-7×15 mm, near administration site left

KIDNEY: Mass, left, TGL-35×53 mm, filled with green fluid SEMINAL VESICLE: Nodule, tan, left, TGL-3 $\times 5 \mathrm{~mm}$ SPLEEN: Enlarged, TGL-small

ADMINISTRATION SITE: Nodule, green, TGL-10×10 mm

SPLEEN- capsule: Focus, white, TGL-15x8mm

PREPUTIAL GLAND: Discoloration, green, left, TGL-small

SKIN-inguinal: Crust, brown, left,-TGL-3×3mm, located near staples SKIN-subcutaneous: Nodule, inguinal, tan, TGL-8x8mm, located under staples, left

SKIN-back: Crust, dark, TGL- $2 \times 2 \mathrm{~mm}$, at port

Tissues were autolyzed

LYMPH NODE-mandibular: Discoloration, red, bilateral TGL-small

LYMPH NODE-mediastinal: Enlarged TGL-small

OVARY: Cyst, clear, right TGL-small

SKIN-subcutaneous: Nodule, inguinal, tan TGL- $5 \times 5 \mathrm{~mm}$

URINARY BLADDER-Nodule: white TGL- $10 \times 0 \mathrm{~mm}$,

on right outer surface

LYMPH NODE-mediastinal: Enlarged, TGL-small

LYMPH NODE 0 iliac: Enlarged, bilateral TGL-small

ADMINISTRATION SITE: Nodule, green TGL-10×10 mm

EYE: Discoloration, dark, right TGL-small

SKIN-subcutaneous: Nodule, inguinal, $\tan$ TGL-10 $\times 10 \mathrm{~mm}$, near

administration site, left

LIVER-all lobes: Discoloration, pale TGL

SKIN-inguinal: Crust, brown, left, multiple TGL- $5 \times 1 \mathrm{~mm}$, near staples LYMPH NODE-iliac: Enlarged, left TGL-small

LYMPH NODE-mediastinal: Enlarged, TGL-small

SKIN-subcutaneous: Nodule, inguinal, tan, left TGL-10×12 mm,

located under staples

Tissues were autolyzed

ADMINISTRATION SITE-subcutaneous: Thick,

clear TGL-small, gelatinous

PREPUTIAL GLAND: Nodule, green, left, TGL- $15 \times 18 \mathrm{~mm}$

ADMINISTRATION SITE: Mass, TGL- $30 \times 30 \mathrm{~mm}$

KIDNEY: Discoloration, pale, left, TGL-small

SEMINAL VESICLE: Adhesion to mass, left, TGL-small

SKIN-tail: Discoloration, dark TGL-small

TESTIS: Discoloration, pale, left, TGL-small

HEART-ventricle: Focus, depressed, right, multiple TGL: $1 \times 1 \mathrm{~mm}$, visible on outside, surface

SKIN-subcutaneous: Nodule, inguinal, dark TGL: $8 \times 11 \mathrm{~mm}$,

left, near administration site

ADMINISTRATION SITE: Nodule, yellow TGL- $8 \times 5 \mathrm{~mm}$

ADRENAL GLAND: Enlarged, bilateral TGL-small

INTESTINE-rectum: Adhesion TGL-small

KIDNEY: Enlarged, mottled, bilateral TGL-small

KIDNEY-pelvis: Dilation, bilateral TGL-small

LUNG-all lobes: Discoloration, mottled TGL-small

LYMPH NODE, mediastinal: Enlarged, mottled TGL-small

THYMUS: TGL-small

URETER: Dilation, bilateral TGL-small

URINARY BLADDER: Enlarged TGL-40×30 mm

CAVITY-pelvic: Nodule, tan TGL- $12 \times 10 \mathrm{~mm}$

EPIDIDYMIS: Adhesion to mass, left TGL-small

KIDNEY: Focus, yellow, multiple TGL $-2 \times 2 \mathrm{~mm}$

KIDNEY-pelvis: Dilation, left TGL-small

LYMPH NODE-mediastinal: Enlarged, bilateral TGL-small

SEMINAL VESICLE: Mass, bilateral TGL- $30 \times 25 \mathrm{~mm}$

TESTIS: Adhesion to mass, red, left TGL-small

THYMUS: Small TGL-small

CAVITY-abdominal: Fluid, clear

HEART-ventricle: Focus, depressed, right, multiple TGL $-2 \times 3 \mathrm{~mm}$, visible on outside, surface

KIDNEY: Focus, yellow, bilateral multiple TGL $-3 \times 3 \mathrm{~mm}$

KIDNEY-pelvis: Dilation, bilateral TGL-small

LYMPH NODE 0 iliac: Enlarged, red TGL-small 


\begin{tabular}{|c|c|c|}
\hline & & $\begin{array}{l}\text { LYMPH NODE-mediastinal: Enlarged, bilateral TGL-small } \\
\text { THYMUS: Small TGL-small }\end{array}$ \\
\hline & & URINARY BLADDER: Enlarged TGL-small \\
\hline & 603 & CAVITY-abdominal: Nodule, green, left TGL- $23 \times 20 \mathrm{~mm}$, perirenal \\
\hline & 605 & SKIN-back: Nodule, subcutaneous, green TGL- $20 \times 20 \mathrm{~mm}$, near port \\
\hline & 609 & EPIDIDYMIS: Thick, left TGL-small \\
\hline & & LYMPH NODE-inguinal: Enlarged, bilateral TGL-small \\
\hline & & LYMPH NODE-mesenteric: Discoloration, dark TGL-small \\
\hline & & $\begin{array}{l}\text { SKIN-inguinal: Nodule, subcutaneous, green TGL } 22 \times 30 \mathrm{~mm} \text {, } \\
\text { near administration site, left }\end{array}$ \\
\hline & & TESTIS: Discoloration, pale, left TGL-small \\
\hline \multirow[t]{19}{*}{$\begin{array}{l}\text { Day } 33 \\
\text { (12 were examined) }\end{array}$} & 619 & $\begin{array}{l}\text { SKIN-subcutaneous: Nodule, inguinal, tan TGL- } 10 \times 8 \mathrm{~mm} \text {, } \\
\text { near administration site, left }\end{array}$ \\
\hline & 621 & LYMPH NODE-iliac: Enlarged, left TGL-small \\
\hline & 631 & LYMPH NODE-iliac: Enlarged, bilateral TGL-small \\
\hline & $633 \mathrm{~b}$ & CAVITY-abdominal: Fluid, clear: gelatinous \\
\hline & & $\begin{array}{l}\text { SKIN-inguinal: Nodule, subcutaneous, green TGL: } 15 \times 30 \mathrm{~mm} \text {, } \\
\text { near administration site }\end{array}$ \\
\hline & & SKIN-tail: Discoloration, dark TGL-small \\
\hline & 635 & SPLEEN-capsule: Focus, white TGL- $3 \times 4$ mm \\
\hline & 592 & LYMPH NODE-iliac: Enlarged, right TGL-small \\
\hline & & SKELETAL MUSCLE-hindlimb: Thick, pale, left TGL-small \\
\hline & & $\begin{array}{l}\text { SKIN, Abdominal-subcutaneous: Mass, mottled, right TGL-7×15 mm } \\
\text { SPLEEN: Enlarged, TGL-small }\end{array}$ \\
\hline & 594 & $\begin{array}{l}\text { SKIN-subcutaneous: Nodule, hindlimb, green, right TGL-20×10 mm } \\
\text { SPLEEN: Enlarged TGL-small }\end{array}$ \\
\hline & 596 & $\begin{array}{l}\text { ADMINISTRATION SITE: Nodule, tan TGL- } 8 \times 8 \mathrm{~mm} \text {, multiple } \\
\text { LYMPH NODE-mediastinal: Enlarged TGL-small }\end{array}$ \\
\hline & 606 & LYMPH NODE-iliac: Enlarged, bilateral TGL-small \\
\hline & & SKIN-subcutaneous: Nodule, inguinal, green TGL- $10 \times 12 \mathrm{~mm}$, under staples \\
\hline & $610 \mathrm{~b}$ & $\begin{array}{l}\text { HEART-apex: Focus, dark TGL- } 2 \times 2 \mathrm{~mm} \text {, may be due to terminal blood } \\
\text { collection via cardiac puncture }\end{array}$ \\
\hline & & URINARY BLADDER: Enlarged TGL-small \\
\hline & 612 & ADMINISTRATION SITE: Nodule, green TGL-20×10 mm \\
\hline & 614 & SKELETAL MUSCLE-abdominal: Mass, green, left TGL- $15 \times 18 \mathrm{~mm}$ \\
\hline & 1122 & SKIN-tail: Discoloration, black TGL-small, tip of tail \\
\hline \multirow{5}{*}{$\begin{array}{l}\text { Day } 33 \\
\text { (12 were examined) }\end{array}$} & 616 & SKIN-back: Crust, brown TGL- $3 \times 1 \mathrm{~mm}$ \\
\hline & & SKIN-back: Laceration TGL- $4 \times 5 \mathrm{~mm}$ \\
\hline & 622 & SKIN-back: Ulcer, TGL-3×4 mm \\
\hline & & $\begin{array}{l}\text { SKIN-subcutaneous: Nodule, back, green TGL- } 20 \times 20 \mathrm{~mm} \text {, over port site, } \\
\text { consistent with a chronic abscess }\end{array}$ \\
\hline & 634 & $\begin{array}{l}\text { ADMINISTRATION SITE-subcutaneous: Nodule, tan TGL- } 18 \times 15 \mathrm{~mm} \\
\text { SKIN-tail: Crust, dark TGL- } 20 \times 5 \mathrm{~mm}\end{array}$ \\
\hline
\end{tabular}

F: Female; M: Male; TGL: Trackable Gross Lesions; ${ }^{\text {a}}$ : Rat 544 was found dead on day 1 and Rat 1116 on day 2. Gross pathology was performed on the same day when the rats were found dead; ${ }^{\text {b }}$ : Moribund euthanasia and gross pathology were performed on day 8 in rats 599 and 601 , day 20 in rat 633 , and day 2 in rat 610

Table 11: Findings from full gross necropsy in minipigs from Experiment B. Full panel necropsy included examination of the carcass and musculoskeletal system, all external surfaces and orifices, cranial cavity and external surface of the brain, thoracic, abdominal and pelvic cavities with their associated organs and tissues

\begin{tabular}{|c|c|c|c|c|}
\hline Group & Sex & $\begin{array}{l}\text { Day } \\
\text { conducted }\end{array}$ & $\begin{array}{l}\text { Mini- } \\
\text { pig\# }\end{array}$ & Observations \\
\hline 1 & $\mathrm{M}$ & $\begin{array}{l}\text { Day } 22 \\
\text { (4 total examined) }\end{array}$ & 1687 & $\begin{array}{l}\text { EPIDIDYMIS: Right, TGL - small } \\
\text { EPIDIDYMIS: Cyst; clear; right, TGL - } 22 \times 20 \mathrm{~mm} \\
\text { TESTIS: Right, TGL - small }\end{array}$ \\
\hline & $\mathrm{F}$ & $\begin{array}{l}\text { Day } 22 \\
\text { (4 total examined) }\end{array}$ & $\begin{array}{l}1686 \\
1688\end{array}$ & $\begin{array}{l}\text { SKIN - hindlimb: Crust, brown, right, multiple, TGL }-10 \times 10 \mathrm{~mm} \\
\text { SKIN - back: Crust, dark, left, multiple, TGL }-5 \times 5 \mathrm{~mm} \\
\text { SKIN - subcutaneous, neck: Nodule, brown, TGL }-20 \times 20 \mathrm{~mm} \\
\text { SKIN - subcutaneous: Accumulation, red, ventral, TGL - small, hematoma per pathologis } \\
\text { THYMUS: Discoloration, red, TGL - small }\end{array}$ \\
\hline 2 & M & $\begin{array}{l}\text { Day } 22 \\
(4 \text { total examined }) \\
\text { Day } 22 \\
(4 \text { total examined })\end{array}$ & $\begin{array}{l}1697 \\
1703 \\
1698\end{array}$ & $\begin{array}{l}\text { SKIN - Neck: Crust, tan, TGL }-5 \times 5 \mathrm{~mm} \\
\text { ADMINISTRATION SITE: Thick, right, TGL - small } \\
\text { LYMPH NODE - bronchial: Discoloration, mottled, TGL - small } \\
\text { SKIN - back: Crust, dark, left, TGL }-5 \times 5 \mathrm{~mm} \text {, at port site } \\
\text { SKIN - neck: Crust, dark, bilateral, TGL }-5 \times 20 \mathrm{~mm}\end{array}$ \\
\hline 3 & M & Dav 22 & $\begin{array}{l}1702 \\
1713\end{array}$ & SKIN - forelimb: Crust, brown, left, TGL $-5 \times 15 \mathrm{~mm}$ \\
\hline
\end{tabular}


Am. J. Pharm. \& Toxicol., 5 (4): 183-208, 2010

Table 11: Continue

(4 total examined)

SKIN - neck: Crust, brown, bilateral, TGL $-5 \times 10 \mathrm{~mm}$

SKIN - forelimb: Laceration, brown, bilateral, TGL $-20 \times 2 \mathrm{~mm}$

1715 LUNG - all lobes: Failed to collapse upon opening of thoracic cavity, discoloration, mottled, TGL - small

LYMPH NODE, MEDIASTINAL - Discoloration, dark, TGL - small

SKIN - back: Nodule, subcutaneous, green, TGL $-7 \times 15 \mathrm{~mm}$; at port site.

SKIN - back: Ulcer, tan, left, multiple, TGL - $4 \times 10 \mathrm{~mm}$, at port site

THYMUS; Discoloration; dark (TGL)

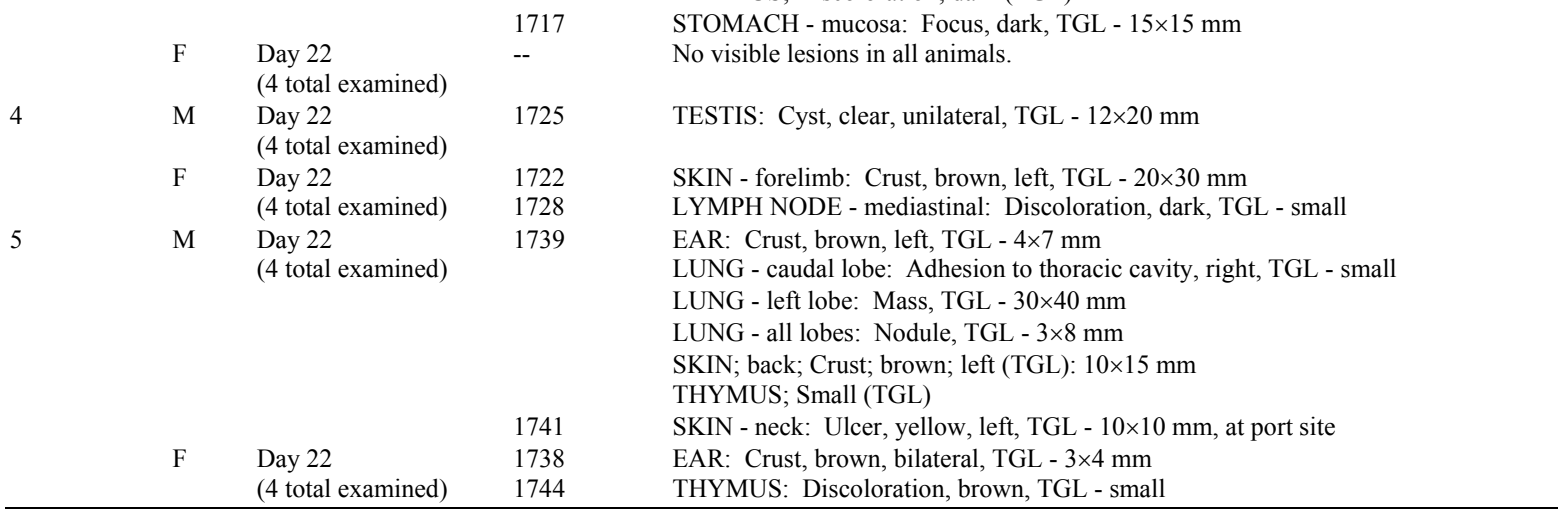

F: Female; M: Male; TGL: Trackable Gross Lesions

Table 12: Summary on the number of rats with histopathology findings from Experiment A. Severity levels are: $\mathrm{A}=$ minimal; $\mathrm{B}=$ mild; $\mathrm{C}=$ moderate; $\mathrm{D}=$ marked. Only tissue/organs with histopathologic findings are listed

\begin{tabular}{|c|c|c|c|c|c|c|c|c|c|c|c|}
\hline \multirow[b]{3}{*}{ Location or tissue type } & \multirow[b]{3}{*}{ Histopathology findings } & \multicolumn{10}{|c|}{ Number of Rats with Histopathology on Day 22 in Main Study } \\
\hline & & \multicolumn{5}{|l|}{ Males } & \multicolumn{5}{|l|}{ Females } \\
\hline & & $\begin{array}{l}\text { Grp1 } \\
\mathrm{n}=12\end{array}$ & $\begin{array}{l}\text { Grp2 } \\
\mathrm{n}=12\end{array}$ & $\begin{array}{l}\text { Grp3 } \\
\mathrm{n}=12\end{array}$ & $\begin{array}{l}\text { Grp4 } \\
\mathrm{n}=12\end{array}$ & $\begin{array}{l}\text { Grp5 } \\
\mathrm{n}=10\end{array}$ & $\begin{array}{l}\text { Grp1 } \\
\mathrm{n}=12\end{array}$ & $\begin{array}{l}\text { Grp2 } \\
\mathrm{n}=12\end{array}$ & $\begin{array}{l}\text { Grp3 } \\
\mathrm{n}=12\end{array}$ & $\begin{array}{l}\text { Grp4 } \\
\mathrm{n}=12\end{array}$ & $\begin{array}{l}\text { Grp5 } \\
\mathrm{n}=12\end{array}$ \\
\hline \multirow[t]{8}{*}{ Administration site } & Hemorrhage & $1 \mathrm{~A}$ & & & & & & 1B & & & \\
\hline & Thrombosis & & & & & & & & 1B & & \\
\hline & Inflam, chronic & $1 \mathrm{~A}$ & $1 \mathrm{~A}, 2 \mathrm{~B}, 1 \mathrm{C}$ & $2 \mathrm{~A}, 1 \mathrm{~B}$ & $1 \mathrm{~A}, 2 \mathrm{~B}$ & $2 \mathrm{~A}, 1 \mathrm{~B}$ & $2 \mathrm{~A}, 3 \mathrm{~B}$ & $1 \mathrm{~A}, 2 \mathrm{~B}$ & $2 \mathrm{~A}, 2 \mathrm{~B}$ & $2 \mathrm{~A}, 2 \mathrm{~B}$ & 1B \\
\hline & Inflam, chronic, active & $1 \mathrm{~B}, 1 \mathrm{C}$ & $4 \mathrm{C}$ & $2 \mathrm{C}, 1 \mathrm{D}$ & $1 \mathrm{~B}, 3 \mathrm{C}$ & $1 \mathrm{~B}, 3 \mathrm{D}$ & $1 \mathrm{~A}, 2 \mathrm{~B}, 1 \mathrm{C}$ & $1 \mathrm{~B}, 1 \mathrm{C}$ & $2 \mathrm{~B}, 1 \mathrm{C}$ & $2 \mathrm{C}$ & $2 \mathrm{~B}, 3 \mathrm{C}, 1 \mathrm{D}$ \\
\hline & Foreign material & 9 & 8 & 5 & 8 & 3 & 1 & 9 & 3 & 4 & 6 \\
\hline & Inflam, granulomatous & $2 \mathrm{~A}, 7 \mathrm{~B}$ & $1 \mathrm{~A}, 2 \mathrm{~B}, 1 \mathrm{C}$ & $1 \mathrm{~A}, 2 \mathrm{~B}, 1 \mathrm{C}$ & $1 \mathrm{~B}, 4 \mathrm{C}$ & $1 \mathrm{~A}, 1 \mathrm{~B}, 1 \mathrm{C}$ & $1 \mathrm{~A}$ & $7 \mathrm{~B}$ & 3B & $1 \mathrm{~A}, 3 \mathrm{~B}, 1 \mathrm{C}$ & $3 \mathrm{~A}, 1 \mathrm{~B}$ \\
\hline & Mineralization & & & & & & & $1 \mathrm{~A}$ & & & \\
\hline & Pigmentation & & & & & & $1 \mathrm{~A}$ & & & & \\
\hline \multirow[t]{2}{*}{ Adrenal gland } & Vacullation, cortex & & & & & & & & & & \\
\hline & Vacuolation, cortex, focal & $1 \mathrm{~A}$ & $1 \mathrm{~A}$ & & & & & & & & \\
\hline \multirow[t]{4}{*}{ Bone marrow, sternum } & Hyperplasia & & & $2 \mathrm{~A}, 1 \mathrm{~B}$ & $4 \mathrm{~A}, 1 \mathrm{~B}, 1 \mathrm{C}$ & $3 \mathrm{~A}, 4 \mathrm{~B}$ & $3 \mathrm{~A}$ & $2 \mathrm{~A}$ & $2 \mathrm{~A}$ & $3 \mathrm{~A}$ & $5 \mathrm{~A}, 1 \mathrm{~B}, 1 \mathrm{C}$ \\
\hline & Granuloma & & & & & & & & & & \\
\hline & Foreign material & & & & & & & & & & \\
\hline & Fibrosis, focal & & & & & & & & & & \\
\hline \multirow[t]{10}{*}{ Bone, femur } & Inflam, chronic & 1B & 1B & & & $2 \mathrm{~B}$ & $1 \mathrm{~A}$ & & & & \\
\hline & Inflam, chronic, periosteum & & & 1B & & & & & & & \\
\hline & Inflam, chronic, synosium & $1 \mathrm{~A}, 1 \mathrm{~B}$ & & & & $1 \mathrm{~B}$ & & & & & \\
\hline & Inflam, chronic, active & & $1 \mathrm{C}$ & & & & & & & $1 \mathrm{C}$ & $1 \mathrm{D}$ \\
\hline & $\begin{array}{l}\text { Inflam, chronic, active, } \\
\text { periosteum }\end{array}$ & & & & $1 \mathrm{C}$ & & & & & & \\
\hline & Foreign material & & 1 & & & & & & & & \\
\hline & Hyperostosis & & & & & $1 \mathrm{~B}$ & & & & & $1 \mathrm{~A}, 1 \mathrm{C}$ \\
\hline & Osteomalacia & & & $1 \mathrm{~A}$ & 1B & & & & & & \\
\hline & Fibrosis & & & & & $1 \mathrm{~A}$ & & & & & $2 \mathrm{~B}$ \\
\hline & $\begin{array}{l}\text { Accessary structure, } \\
\text { physis, cartilage }\end{array}$ & & & & & & & & & & \\
\hline \multirow[t]{5}{*}{ Bone, sternum } & Degeneration & & & & & & & & & & \\
\hline & $\begin{array}{l}\text { Degeneration, cartilage } \\
\text { Inflam, chronic, cartilage }\end{array}$ & $1 \mathrm{~A}$ & $1 \mathrm{~A}$ & & 1B & $1 \mathrm{~A}$ & $3 \mathrm{~A}$ & $3 \mathrm{~A}$ & $3 \mathrm{~A}$ & $6 \mathrm{~A}$ & $2 \mathrm{~A}$ \\
\hline & Inflam, chronic & & & & & & & & & $1 \mathrm{~B}$ & \\
\hline & Inflam, chronic, active & & & & & & & & & 1B & \\
\hline & Hyperostosis & & & & & & & & & 1B & \\
\hline Cervix & Cyst & & & & & & & & & & \\
\hline Cavity, abdominal & Inflam, chronic, active & & & & $1 \mathrm{D}$ & & & & & & \\
\hline \multirow{5}{*}{ Epididymis } & Granuloma, spermatic, unilateral & & & & & 1D & -- & -- & -- & -- & -- \\
\hline & $\begin{array}{l}\text { Granuloma, } \\
\text { spermatogenic, unilateral }\end{array}$ & & & & & $1 \mathrm{D}$ & -- & -- & -- & -- & -- \\
\hline & Inflam, chronic, active & & & 1D & & & -- & -- & -- & -- & -- \\
\hline & Infiltration, lymphocytic & $1 \mathrm{~A}$ & & & & & -- & -- & -- & -- & -- \\
\hline & Ulceration, cornea & & & & & & & & & 1D & \\
\hline
\end{tabular}


Am. J. Pharm. \& Toxicol., 5 (4): 183-208, 2010

Table 12: Continue

\begin{tabular}{|c|c|c|c|c|c|c|c|c|c|c|c|}
\hline & $\begin{array}{l}\text { Inflam, chronic, cornea } \\
\text { Inflam, chronic, muscle } \\
\text { Inflam, chronic, muscle, unilater }\end{array}$ & & & & $1 \mathrm{~A}$ & & & & & & \\
\hline & $\begin{array}{l}\text { Mineralization, cornea } \\
\text { Inflam, chronic, active }\end{array}$ & & & & & & & & & $1 \mathrm{D}$ & \\
\hline & Inflam, chronic, active, cornea & $1 \mathrm{C}$ & & & & & & & & & \\
\hline & Phthisis Bulbi, unilateral & 1D & & & & & & & & & \\
\hline Harderian gland & Inflam, chronic, bilateral & & & & & & & $1 \mathrm{C}$ & & & \\
\hline & $\begin{array}{l}\text { Inflam, chronic, unilateral } \\
\text { Inflam, chronic, active }\end{array}$ & & 1B & & $1 \mathrm{~A}$ & $1 \mathrm{~A}$ & & & & $\begin{array}{l}1 \mathrm{~A}, 2 \mathrm{~B} \\
1\end{array}$ & $1 \mathrm{~A}$ \\
\hline & Infiltration, lymphocytic & & & & & & & & $1 \mathrm{~A}$ & & \\
\hline Heart & Hemorrhage, myocardium & & & & & & & & & & \\
\hline & $\begin{array}{l}\text { Cardiomyopathy } \\
\text { Fibrosis, focal }\end{array}$ & & & & & 1A.1C & $1 \mathrm{~A}$ & & & $1 \mathrm{~A}$ & \\
\hline & Inflam, chronic, active, valve & & & & & & & & & & $1 \mathrm{D}$ \\
\hline & Bacteremia & & & & & & & & & & 1 \\
\hline Intestine, cecum & Inflam, chronic & & $1 \mathrm{~A}$ & & $1 \mathrm{~A}$ & & & & & & \\
\hline Intestine, duodenum & $\begin{array}{l}\text { Inflam, chronic } \\
\text { Inflam, chronic, serosa }\end{array}$ & & & 1B & $1 \mathrm{~A}$ & & & & & & \\
\hline Intestine, ileum & Inflam, chronic & & $1 \mathrm{~A}$ & & $1 \mathrm{~A}$ & & $3 \mathrm{~A}$ & $2 \mathrm{~A}$ & $2 \mathrm{~A}$ & $1 \mathrm{~A}$ & $2 \mathrm{~A}$ \\
\hline Intestine, jejunum & Inflam, chronic & $1 \mathrm{~A}$ & & & & & $1 \mathrm{~A}$ & $1 \mathrm{~A}$ & & $2 \mathrm{~A}$ & $1 \mathrm{~A}$ \\
\hline Intestine, rectum & $\begin{array}{l}\text { Inflam, chronic, serosa } \\
\text { Inflam, chronic, active }\end{array}$ & & & & & $\begin{array}{l}1 \mathrm{~A} \\
1 \mathrm{C}\end{array}$ & & & & & \\
\hline Kidney & Cyst & & & & & & & & & & \\
\hline & $\begin{array}{l}\text { Chronic, progressive, } \\
\text { nephropathy }\end{array}$ & $1 \mathrm{~A}$ & $9 \mathrm{~A}$ & $8 \mathrm{~A}, 1 \mathrm{~B}$ & $1 \mathrm{~A}, 1 \mathrm{~B}$ & $6 \mathrm{~A}$ & $7 \mathrm{~A}$ & $5 \mathrm{~A}$ & $4 \mathrm{~A}$ & $8 \mathrm{~A}$ & $9 \mathrm{~A}$ \\
\hline & Degeneration, tubule & $1 \mathrm{~A}$ & & & & $1 \mathrm{~A}$ & & & $1 \mathrm{~A}$ & & \\
\hline & $\begin{array}{l}\text { Hyperplasia, transitional } \\
\text { cell, epithelium }\end{array}$ & & & & & 1B & & & & & \\
\hline & Mineralization & $1 \mathrm{~A}$ & & & & $1 \mathrm{~A}$ & & & & & \\
\hline & Mineralization, pelvic & & & $2 \mathrm{~A}$ & & & & & & & \\
\hline & Inflam, chronic, capsule & & & & 1B & 1B & & & $1 \mathrm{~A}$ & & \\
\hline & Inflam, chronic, active & & & & & $1 \mathrm{C}, 1 \mathrm{D}$ & & & & & \\
\hline & Inflam, chronic, active, pelvis & & & & & $1 \mathrm{~A}$ & & & & & \\
\hline & Dilation, pelvis & & & & 1B & $1 \mathrm{~A}$ & & & & $1 \mathrm{~A}$ & \\
\hline & Inflitration, lymphocytic & & & & & $1 \mathrm{~A}$ & & & & & \\
\hline Liver & Hematopoiesis, increased & & & & 1B & $1 \mathrm{~A}$ & & $1 \mathrm{~A}$ & & $1 \mathrm{~A}$ & 3A. $1 \mathrm{~B}$ \\
\hline trit & $\begin{array}{l}\text { Hypertropy, Kupffer cell } \\
\text { Infiltration, histiocytic }\end{array}$ & & & & & $1 \mathrm{~A}$ & & 111 & & & $1 \mathrm{~B}$ \\
\hline & $\begin{array}{l}\text { Infiltration, lymphohistiocytic } \\
\text { Necrosis }\end{array}$ & $1 \mathrm{~A}$ & $1 \mathrm{~A}$ & $5 \mathrm{~A}$ & $\begin{array}{l}2 \mathrm{~A} \\
1 \mathrm{~A}\end{array}$ & $2 \mathrm{~A}$ & $5 \mathrm{~A}$ & $4 \mathrm{~A}$ & $3 \mathrm{~A}$ & $4 \mathrm{~A}$ & $3 \mathrm{~A}$ \\
\hline & $\begin{array}{l}\text { Necrosis } \\
\text { Necrosis, single cell }\end{array}$ & & & & & & & & & $1 \mathrm{~A}$ & \\
\hline & Inflam, chronic, capsule & & $1 \mathrm{~A}$ & & $1 \mathrm{~B}$ & & & & & & \\
\hline & Thrombosis, vein & & & & & & & & & & $1 \mathrm{~A}$ \\
\hline & Hepatodiaphragmatic nodule & & & & & & 1 & & & & \\
\hline & Vacuolation, & & & & & & & & & & \\
\hline Lung & $\begin{array}{l}\text { hepatocyte, cytoplasm } \\
\text { Foreign material }\end{array}$ & 2 & 1 & & & 1 & & & 1 & 3 & \\
\hline & Hemorrhage & & & & & $1 \mathrm{~A}$ & $1 \mathrm{~A}$ & & & $1 \mathrm{~A}, 1 \mathrm{~B}$ & \\
\hline & $\begin{array}{l}\text { Hyperplasia, alveolar } \\
\text { epithelium, focal }\end{array}$ & & $1 \mathrm{C}$ & & & & & & & & \\
\hline & Granuloma & $1 \mathrm{~A}$ & $1 \mathrm{~A}$ & $2 \mathrm{~A}$ & $1 \mathrm{~A}$ & & & & $1 \mathrm{~A}$ & $2 \mathrm{~A}$ & \\
\hline & Granuloma, vein & & & & & & & & & 1B & \\
\hline & Granuloma, vein, multiple & & & & & 1B & & & & & \\
\hline & Inflam, subacute & & & & & & & & $1 \mathrm{~A}$ & & \\
\hline & Inflam, Subacute, periarterial & & $1 \mathrm{~A}$ & & & & & & & & \\
\hline & Inflam, granulomatous & & & & & & & & & $1 \mathrm{~A}$ & $1 \mathrm{~A}$ \\
\hline & Inflam, granulomatous, focal & & & & & & & & & $1 \mathrm{~A}$ & \\
\hline & $\begin{array}{l}\text { Inflam, granulomatous, } \\
\text { periarterial }\end{array}$ & $1 \mathrm{~A}$ & & & & & & & & & \\
\hline & Inflam, chronic & $3 \mathrm{~A}, 1 \mathrm{~B}$ & & $1 \mathrm{~A}$ & & & $1 \mathrm{~A} .2 \mathrm{~B}$ & $2 \mathrm{~A}, 1 \mathrm{~B}$ & 1B & $2 \mathrm{~A}$ & $1 \mathrm{~A}$ \\
\hline & Inflam, chronic, interstitium & & & $1 \mathrm{~A}, 1 \mathrm{C}$ & & $1 \mathrm{~B}$ & & & & & \\
\hline & Inflam, chronic, arterial & & & & & & & $1 \mathrm{~A}$ & & & \\
\hline & Inflam, chronic, active & & & & $1 \mathrm{~A}$ & & & & & & \\
\hline & Inflam, chronic, active, artery & 1A.1B & & & & & & & & & \\
\hline & Histiocytosis, focal & $1 \mathrm{~A}$ & & & & & & & & & \\
\hline & Metaplasia, osseous & & & & & $1 \mathrm{~A}$ & & & & & \\
\hline & Hypertrophy, artery & & & & & & 1A.1B & $1 \mathrm{~A}, 1 \mathrm{~B}$ & & & \\
\hline & Pigmentation & & & & & & $1 \mathrm{~A}$ & & & & \\
\hline Lymph node, iliac & Hemorrhage & & & & $1 \mathrm{~B}$ & & & & & & \\
\hline & Hyperplasia, lymphoid & & & & & & & 1C & & & $2 \mathrm{C}$ \\
\hline & Hyperplasia, lymphoid, mucosal & & & & & & & & & & \\
\hline Lymph node, inguinal & Inflam, chronic, active & & & & 1D & & & & & & \\
\hline & Hyperplasia, lymphoid, bilateral & & & & & $1 \mathrm{C}$ & & & & & \\
\hline Lymph node, mediastinal & 1 hyperplasia, lymphoid & & & & & $1 \mathrm{~A}$ & & & & $1 \mathrm{~A}, 1 \mathrm{~B}$ & $1 \mathrm{~A}$ \\
\hline & Hemorrhage & & & & & $1 \mathrm{~A}$ & & & & & \\
\hline & Edema & & & & & & & & & 1B & \\
\hline Lymph node, mesenteric & Atrophy & & & & & 1B & & & & & \\
\hline & Hyperplasia, lymphoid & & $1 \mathrm{~A}$ & $1 \mathrm{~A}$ & & $1 \mathrm{~A}$ & $1 \mathrm{~A}$ & & & & \\
\hline
\end{tabular}


Am. J. Pharm. \& Toxicol., 5 (4): 183-208, 2010

Table 12: Continue

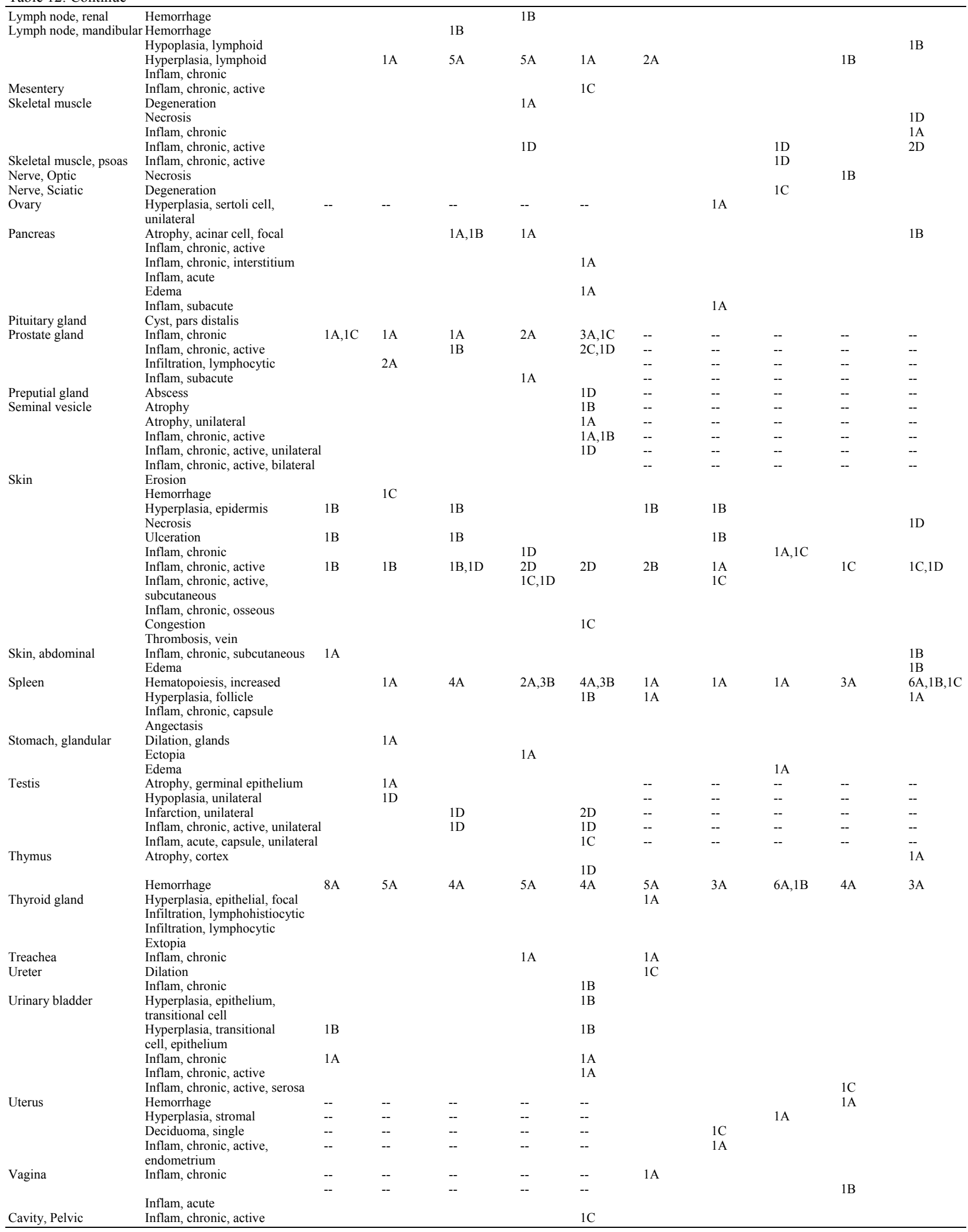


Am. J. Pharm. \& Toxicol., 5 (4): 183-208, 2010

Table 12: Continue

\begin{tabular}{|c|c|c|c|c|c|c|c|c|c|}
\hline \multirow[b]{3}{*}{ Location or Tissue Type } & \multirow[b]{3}{*}{ Histopathology findings } & \multicolumn{8}{|c|}{ Number of Rats with Histopathology on Day 33 in Recovery Study } \\
\hline & & \multicolumn{4}{|l|}{ Males } & \multicolumn{4}{|c|}{ Females } \\
\hline & & $\begin{array}{l}\text { Grp1 } \\
n=12\end{array}$ & $\begin{array}{l}\text { Grp2 } \\
\mathrm{n}=12\end{array}$ & $\begin{array}{l}\text { Grp4 } \\
\mathrm{n}=12\end{array}$ & $\begin{array}{l}\text { Grp5 } \\
\mathrm{n}=11\end{array}$ & $\begin{array}{l}\text { Grp1 } \\
\mathrm{n}=12\end{array}$ & $\begin{array}{l}\text { Grp2 } \\
\mathrm{n}=12\end{array}$ & $\begin{array}{l}\text { Grp4 } \\
\mathrm{n}=12\end{array}$ & $\begin{array}{l}\text { Grp5 } \\
\mathrm{n}=12\end{array}$ \\
\hline \multirow[t]{6}{*}{ Administration site } & $\begin{array}{l}\text { Hemorrhage } \\
\text { Thrombosis }\end{array}$ & & & & & & & & \\
\hline & Inflam, chronic & $2 \mathrm{~A}, 1 \mathrm{~B}$ & $6 \mathrm{~A}, 1 \mathrm{~B}$ & $3 \mathrm{~A}, 5 \mathrm{~B}$ & $1 \mathrm{C}$ & $5 \mathrm{~A}, 1 \mathrm{~B}$ & $3 \mathrm{~A}$ & $3 \mathrm{~A}, 4 \mathrm{~B}$ & 1B \\
\hline & Inflam, chronic, active & & & $1 \mathrm{~B}, 1 \mathrm{D}$ & & $2 \mathrm{~B}, 1 \mathrm{C}$ & $3 \mathrm{C}, 2 \mathrm{D}$ & $1 \mathrm{C}$ & $1 \mathrm{~B}, 2 \mathrm{C}, 1 \mathrm{D}$ \\
\hline & Foreign material & 9 & 1 & & 1 & 3 & 12 & 2 & \\
\hline & Inflam, granulomatous & $3 \mathrm{~A}, 6 \mathrm{~B}$ & $1 \mathrm{~A}$ & & $3 \mathrm{~A}, 6 \mathrm{~B}, 1 \mathrm{C}$ & $1 \mathrm{~A}$ & $1 \mathrm{~A}, 3 \mathrm{~B}$ & $2 \mathrm{~B}$ & $1 \mathrm{~A}, 5 \mathrm{~B}, 1 \mathrm{C}$ \\
\hline & $\begin{array}{l}\text { Mineralization } \\
\text { Pigmentation }\end{array}$ & & & & & & & $1 \mathrm{~A}$ & \\
\hline \multirow{2}{*}{ Adrenal gland } & Vacullation, cortex & $1 \mathrm{~A}$ & & $1 \mathrm{~A}$ & & & & & \\
\hline & Vacuolation, cortex, focal & & & & & & $1 \mathrm{~A}$ & & \\
\hline \multirow[t]{4}{*}{ Bone marrow, sternum } & Hyperplasia & & & $4 \mathrm{~A}, 1 \mathrm{~B}$ & & $2 \mathrm{~A}$ & $5 \mathrm{~A}$ & $1 \mathrm{~A}$ & $3 \mathrm{~A}, 2 \mathrm{~B}$ \\
\hline & Granuloma & & & & & & & & $1 \mathrm{~B}$ \\
\hline & Foreign material & & & & & & & & 1 \\
\hline & Fibrosis, focal & & & & & & $1 \mathrm{~A}$ & & \\
\hline \multirow[t]{9}{*}{ Bone, femur } & Inflam, chronic & $1 \mathrm{~A}$ & & $1 \mathrm{~B}$ & $1 \mathrm{~A}, 1 \mathrm{~B}$ & $1 \mathrm{~A}$ & $2 \mathrm{~B}$ & $1 \mathrm{~A}$ & 1B \\
\hline & $\begin{array}{l}\text { Inflam, chronic, periosteum } \\
\text { Inflam, chronic, synosium }\end{array}$ & & & & & & & & \\
\hline & Inflam, chronic, active & & & & & & & $2 \mathrm{~B}$ & \\
\hline & Inflam, chronic, active, periosteum & & & & & & & & \\
\hline & Foreign material & & & & & & 1 & & \\
\hline & Hyperostosis & & & & $1 \mathrm{~A}$ & & $1 \mathrm{~B}$ & & \\
\hline & Osteomalacia & & & & & & & & \\
\hline & Fibrosis & & & & & & & & \\
\hline & Accessary structure, physis, cartilage & & & 1 & & & & & \\
\hline \multirow[t]{6}{*}{ Bone, sternum } & Degeneration & & $1 \mathrm{~B}$ & & & $1 \mathrm{~A}$ & & & \\
\hline & Degeneration, cartilage & $2 \mathrm{~A}, 1 \mathrm{~B}$ & $2 \mathrm{~A}$ & $3 \mathrm{~A}$ & $4 \mathrm{~A}$ & $9 \mathrm{~A}$ & $8 \mathrm{~A}, 1 \mathrm{~B}$ & $8 \mathrm{~A}$ & $1 \mathrm{~A}, 2 \mathrm{~B}$ \\
\hline & Inflam, chronic, cartilage & & & & & & $1 \mathrm{~B}$ & & \\
\hline & Inflam, chronic & & & & & & & & \\
\hline & Inflam, chronic, active & & & & & & & & \\
\hline & Hyperostosis & & & & & & & & \\
\hline Cervix & Cyst & -- & -- & -- & -- & & 1 & & \\
\hline Cavity, abdominal & Inflam, chronic, active & & & & & & & & \\
\hline \multirow{4}{*}{ Epididymis } & Granuloma, spermatic, unilateral & & & & & & & & \\
\hline & Granuloma, spermatogenic, unilateral & & & & & & & & \\
\hline & Inflam, chronic, active & & & & & & & & \\
\hline & Infiltration, lymphocytic & & & & & & & & \\
\hline Eye & Ulceration, cornea & & & & & & & & \\
\hline & Inflam, chronic, cornea & & & & & & $1 \mathrm{~A}$ & & 1B \\
\hline & Inflam, chronic, muscle & & & & & 1B & & & \\
\hline & Inflam, chronic, muscle, unilateral & & & & $1 \mathrm{~A}$ & & & & \\
\hline & Mineralization, cornea & & & & & 1B & $1 \mathrm{~A}$ & & $1 \mathrm{~A}$ \\
\hline & Inflam, chronic, active & & & & & & & & \\
\hline & Inflam, chronic, active, cornea & & & & & & & & \\
\hline & Phthisis Bulbi, unilateral & & & & & & & & \\
\hline Harderian gland & Inflam, chronic, bilateral & & & & & & & & \\
\hline & Inflam, chronic, unilateral & $1 \mathrm{~B}$ & & & & 1B & $1 \mathrm{~A}$ & $2 \mathrm{~A}$ & \\
\hline & Inflam, chronic, active & & & & & & & & \\
\hline & Infiltration, lymphocytic & & & & & & & & \\
\hline Heart & Hemorrhage, myocardium & & & & & & & 1B & \\
\hline & Cardiomyopathy & & $2 \mathrm{~A}$ & & & $1 \mathrm{~A}$ & & & \\
\hline & Fibrosis, focal & & & & & & & & $1 \mathrm{~A}$ \\
\hline & Inflam, chronic, active, valve & & & & & & & & \\
\hline & Bacteremia & & & & & & & & \\
\hline Intestine, cecum & Inflam, chronic & & & & & & & & \\
\hline Intestine, duodenum & Inflam, chronic & $1 \mathrm{~A}$ & & & & & & $1 \mathrm{~A}$ & \\
\hline & Inflam, chronic, serosa & & & & & & & & \\
\hline Intestine, ileum & Inflam, chronic & & $3 \mathrm{~A}$ & $1 \mathrm{~A}$ & $2 \mathrm{~A}$ & $4 \mathrm{~A}$ & $3 \mathrm{~A}$ & & $1 \mathrm{~A}$ \\
\hline Intestine, jejunum & Inflam, chronic & $1 \mathrm{~A}$ & & $1 \mathrm{~A}$ & $3 \mathrm{~A}$ & $1 \mathrm{~A}$ & $1 \mathrm{~A}$ & & $1 \mathrm{~A}$ \\
\hline Intestine, rectum & Inflam, chronic, serosa & & & & & & & & \\
\hline & Inflam, chronic, active & & & & & & & & \\
\hline Kidney & Cyst & 1 & 1 & & & 1 & 1 & 1 & \\
\hline & Chronic, progressive, nephropathy & $11 \mathrm{~A}$ & $11 \mathrm{~A}$ & $8 \mathrm{~A}, 1 \mathrm{~B}$ & $1 \mathrm{~A}$ & $5 \mathrm{~A}$ & $6 \mathrm{~A}, 1 \mathrm{~B}$ & $8 \mathrm{~A}$ & $6 \mathrm{~A}, 1 \mathrm{~B}$ \\
\hline & Degeneration, tubule & & & & & $1 \mathrm{~A}$ & & & \\
\hline & $\begin{array}{l}\text { Hyperplasia, transitional } \\
\text { cell, epithelium }\end{array}$ & & & & & & & & \\
\hline & Mineralization & & & & $1 \mathrm{~A}$ & $2 \mathrm{~A}$ & & $1 \mathrm{~A}$ & \\
\hline & Mineralization, pelvic & & & & & & & & \\
\hline & Inflam, chronic, capsule & & & & & & & & 1B \\
\hline
\end{tabular}


Am. J. Pharm. \& Toxicol., 5 (4): 183-208, 2010

Table 12: Continue

\begin{tabular}{|c|c|c|c|c|c|c|c|c|c|}
\hline & $\begin{array}{l}\text { Inflam, chronic, active } \\
\text { Inflam, chronic, active, pelvis }\end{array}$ & & & 1D & & & & & \\
\hline & Dilation, pelvis & & & $1 \mathrm{~A}$ & & & & & \\
\hline & Inflitration, lymphocytic & & & & & & & & \\
\hline \multirow{8}{*}{ Liver } & Hematopoiesis, increased & & & $1 \mathrm{~A}$ & & & & & \\
\hline & $\begin{array}{l}\text { Hypertropy, Kupffer cell } \\
\text { Infiltration, histiocytic }\end{array}$ & & & & & & & & \\
\hline & Infiltration, lymphohistiocytic & $1 \mathrm{~A}$ & $3 \mathrm{~A}$ & $1 \mathrm{~A}$ & & $2 \mathrm{~A}$ & $4 \mathrm{~A}$ & $2 \mathrm{~A}$ & $1 \mathrm{~A}$ \\
\hline & Necrosis & & & & & & & & \\
\hline & Necrosis, single cell & & & & & & & & \\
\hline & Inflam, chronic, capsule & & & & & & & & \\
\hline & $\begin{array}{l}\text { Thrombosis, vein } \\
\text { Hepatodiaphragmatic nodule }\end{array}$ & & 1 & & & & & & \\
\hline & Vacuolation, hepatocyte, cytoplasm & & & & & & $1 \mathrm{~A}$ & & \\
\hline \multirow{19}{*}{ Lung } & Foreign material & & 2 & & & 2 & & & \\
\hline & Hemorrhage & & & & & & & & \\
\hline & Hyperplasia, alveolar epithelium, focal & & & & & & & & \\
\hline & Granuloma & & $1 \mathrm{~A}$ & & & $2 \mathrm{~A}$ & & & \\
\hline & Granuloma, vein & & & & & & & & \\
\hline & Granuloma, vein, multiple & & & & & & & & \\
\hline & Inflam, subacute & & & & & & & & \\
\hline & Inflam, Subacute, periarterial & & & & & & & & \\
\hline & Inflam, granulomatous & & & & & & & & \\
\hline & Inflam, granulomatous, focal & & & & & & & & \\
\hline & Inflam, granulomatous, periarterial & & & & & & & & \\
\hline & Inflam, chronic & & & $2 \mathrm{~A}$ & & $1 \mathrm{~A}$ & & & \\
\hline & Inflam, chronic, interstitium & & & & & & & & \\
\hline & Inflam, chronic, arterial & $1 \mathrm{~A}$ & $1 \mathrm{~A}$ & & & & & & \\
\hline & $\begin{array}{l}\text { Inflam, chronic, active } \\
\text { Inflam, chronic, active, artery }\end{array}$ & & & & & & & & \\
\hline & Histiocytosis, focal & $1 \mathrm{~A}$ & & & & & & $1 \mathrm{~A}$ & \\
\hline & Metaplasia, osseous & & $1 \mathrm{~A}$ & & & & & & \\
\hline & Hypertrophy, artery & & & & & & & & \\
\hline & Pigmentation & & & & & & & & \\
\hline \multirow[t]{3}{*}{ Lymph node, iliac } & Hemorrhage & & & & & & & & \\
\hline & Hyperplasia, lymphoid & & & & 1B & & & $1 \mathrm{C}$ & \\
\hline & Hyperplasia, lymphoid, mucosal & & & & 1B & & & & \\
\hline \multirow{2}{*}{ Lymph node, inguinal } & Inflam, chronic, active & & & & & & & & \\
\hline & Hyperplasia, lymphoid, bilateral & & & & & & & & \\
\hline \multirow[t]{3}{*}{ Lymph node, mediastinal } & hyperplasia, lymphoid & & & & & & & $1 \mathrm{~A}$ & \\
\hline & Hemorrhage & & & & & & & $1 \mathrm{~B}$ & \\
\hline & Edema & & & & & & & & \\
\hline \multirow[t]{2}{*}{ Lymph node, mesenteric } & Atrophy & & & & & & & & \\
\hline & Hyperplasia, lymphoid & & $1 \mathrm{~A}$ & & & & & & \\
\hline Lymph node, renal & Hemorrhage & & & & & & & & \\
\hline \multirow[t]{4}{*}{ Lymph node, mandibular } & Hemorrhage & & & $1 \mathrm{~A}$ & & & $1 \mathrm{~A}$ & & \\
\hline & Hypoplasia, lymphoid & & & & & & & & \\
\hline & Hyperplasia, lymphoid & $3 \mathrm{~A}$ & $4 \mathrm{~A}$ & $2 \mathrm{~A}, 1 \mathrm{~B}$ & 1B & $2 \mathrm{~A}$ & $1 \mathrm{~A}$ & & $2 \mathrm{~A}$ \\
\hline & Inflam, chronic & & & $1 \mathrm{~A}$ & & & & & \\
\hline Mesentery & Inflam, chronic, active & & & & & & & & \\
\hline \multirow[t]{4}{*}{ Skeletal muscle } & Degeneration & & & & & & & & \\
\hline & Necrosis & & & & & & & & \\
\hline & Inflam, chronic & & & & & & & & \\
\hline & Inflam, chronic, active & & & & & & & & \\
\hline Skeletal muscle, psoas & Inflam, chronic, active & & & & & & & & \\
\hline Nerve, Optic & Necrosis & & & & & & & & \\
\hline Nerve, Sciatic & Degeneration & $1 \mathrm{~A}$ & & & & 1B & & & \\
\hline Ovary & Hyperplasia, sertoli cell, unilateral & & & & & & & & \\
\hline \multirow[t]{6}{*}{ Pancreas } & Atrophy, acinar cell, focal & & & & & & & $1 \mathrm{~A}$ & \\
\hline & Inflam, chronic, active & & & 1B & & & & & \\
\hline & Inflam, chronic, interstitium & & & & & & & & \\
\hline & Inflam, acute & & & & & $1 \mathrm{C}$ & & & \\
\hline & Edema & & & & & & & & \\
\hline & Inflam, subacute & & & & & & & & \\
\hline Pituitary gland & Cyst, pars distalis & 2 & & & 1 & & & & \\
\hline Prostate gland & Inflam, chronic & $1 \mathrm{~A}$ & & $2 \mathrm{~A}$ & $1 \mathrm{~A}, 1 \mathrm{C}$ & -- & -- & -- & -- \\
\hline & Inflam, chronic, active & & & $1 \mathrm{~B}, 1 \mathrm{C}$ & & -- & -- & -- & -- \\
\hline & Infiltration, lymphocytic & & & & & -- & -- & -- & -- \\
\hline & Inflam, subacute & & & & & -- & -- & -- & -- \\
\hline Preputial gland & Abscess & & & 1D & & -- & -- & -- & -- \\
\hline Seminal vesicle & Atrophy & & & & & -- & -- & -- & -- \\
\hline & Atrophy, unilateral & & & & & -- & -- & -- & -- \\
\hline & Inflam, chronic, active & & & 1D & & -- & -- & -- & -- \\
\hline & Inflam, chronic, active, unilateral & & & & & -- & -- & -- & -- \\
\hline & Inflam, chronic, active, bilateral & & & & 1D & -- & -- & -- & -- \\
\hline
\end{tabular}


Am. J. Pharm. \& Toxicol., 5 (4): 183-208, 2010

Table 12: Continue

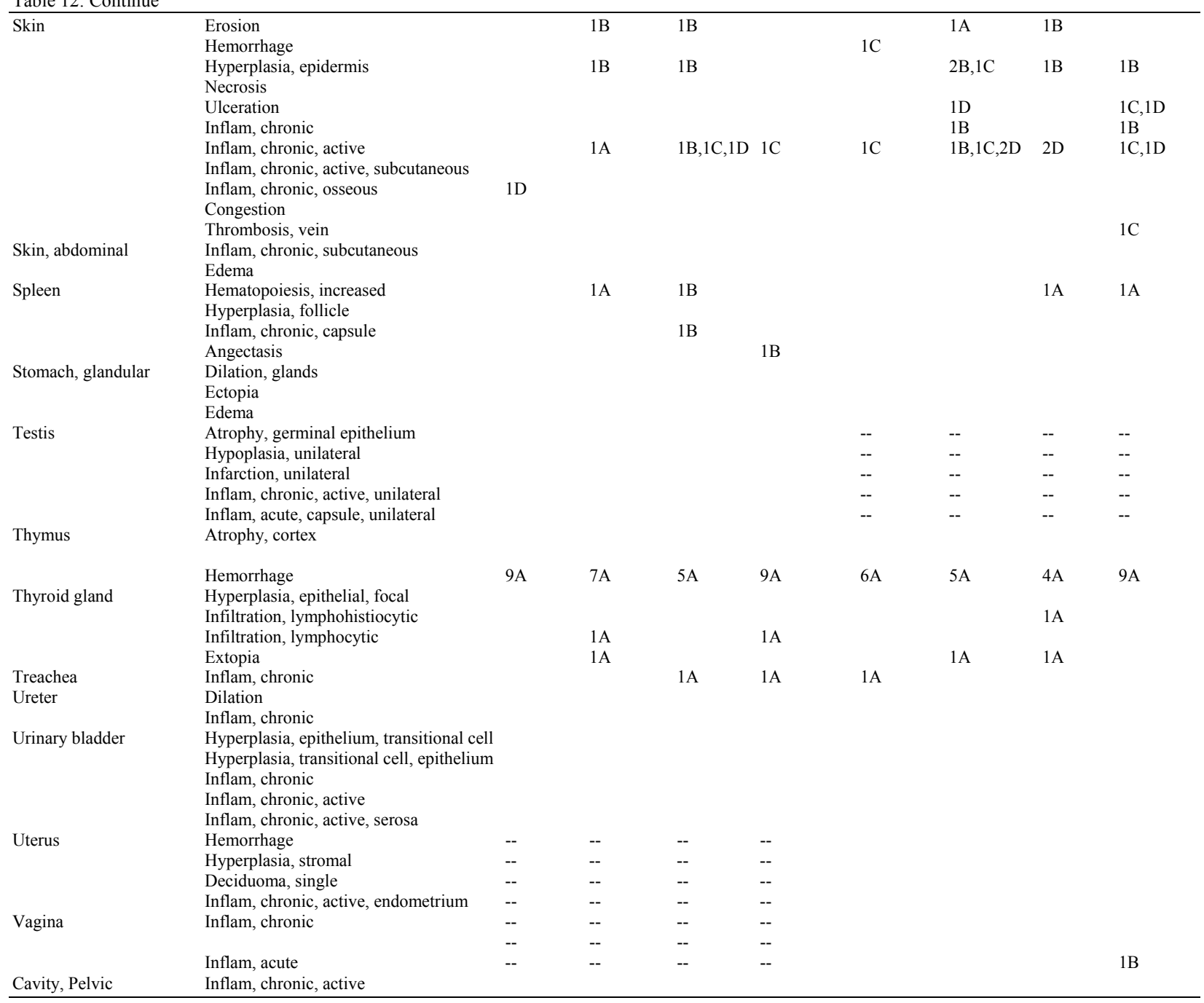

Table 13: Summary on the number of minipigs with histopathology findings from Experiment B. Severity levels are: $A=$ minimal; B = mild; C $=$ moderate $; \mathrm{D}=$ marked. Only tissue/organs with histopathologic findings are listed. Histology was performed on day 22

\begin{tabular}{|c|c|c|c|c|c|c|c|c|c|c|c|}
\hline \multirow[b]{2}{*}{ Location or Tissue Type } & \multirow[b]{2}{*}{ Histopathology findings } & \multicolumn{5}{|l|}{ Males } & \multicolumn{5}{|c|}{ Females } \\
\hline & & $\begin{array}{l}\text { Grp1 } \\
\mathrm{n}=4\end{array}$ & $\begin{array}{l}\text { Grp2 } \\
\mathrm{n}=4\end{array}$ & $\begin{array}{l}\text { Grp3 } \\
n=4\end{array}$ & $\begin{array}{l}\text { Grp4 } \\
n=4\end{array}$ & $\begin{array}{l}\text { Grp5 } \\
\mathrm{n}=4\end{array}$ & $\begin{array}{l}\text { Grp1 } \\
n=4\end{array}$ & $\begin{array}{l}\text { Grp2 } \\
\mathrm{n}=4\end{array}$ & $\begin{array}{l}\text { Grp3 } \\
\mathrm{n}=4\end{array}$ & $\begin{array}{l}\text { Grp4 } \\
n=4\end{array}$ & $\begin{array}{l}\text { Grp5 } \\
\mathrm{n}=4\end{array}$ \\
\hline \multirow[t]{5}{*}{ Administration site } & Hemorrage & & & & & & $1 \mathrm{C}$ & & $1 \mathrm{~B}$ & & \\
\hline & Infiltration, lymphocytic & $1 \mathrm{~B}$ & $1 \mathrm{C}$ & & & & & & & $1 \mathrm{C}$ & \\
\hline & Inflammation, chronic, active & & $1 \mathrm{D}$ & $2 \mathrm{D}$ & & & & & & $1 \mathrm{~B}$ & $1 \mathrm{C}$ \\
\hline & Thrombosis & $1 \mathrm{~A}, 1 \mathrm{~B}$ & $2 \mathrm{C}$ & $1 \mathrm{~B}$ & & $1 \mathrm{~B}, 1 \mathrm{C}$ & $1 \mathrm{~B}, 2 \mathrm{C}$ & $2 \mathrm{~B}$ & $1 \mathrm{~A}, 2 \mathrm{~B}$ & $2 \mathrm{C}$ & \\
\hline & Thrombosis, bilateral & $1 \mathrm{~B}, 1 \mathrm{C}$ & $1 \mathrm{C}, 1 \mathrm{D}$ & $1 \mathrm{C}, 1 \mathrm{D}$ & $1 \mathrm{~A}, 1 \mathrm{C}, 1 \mathrm{D}$ & $2 \mathrm{~B}$ & $1 \mathrm{C}$ & $2 \mathrm{C}$ & $1 \mathrm{C}$ & $2 \mathrm{C}$ & $3 \mathrm{C}$ \\
\hline Bone marrow, sternum & Hyperplasia & & & & & $1 \mathrm{D}$ & & & & & \\
\hline Brain, brain stem & Hemorrhage, multifocal & $1 \mathrm{~B}$ & & & & & $2 \mathrm{~A}$ & & & $1 \mathrm{~A}$ & \\
\hline Brain, cerebellum & Hemorrhage, multifocal & & & & & & & & $2 \mathrm{~A}$ & & \\
\hline Brain, cerebrum & Hemorrhage, multifocal & $1 \mathrm{~A}$ & & $1 \mathrm{~A}$ & $1 \mathrm{~A}$ & $1 \mathrm{~A}$ & $1 \mathrm{~A} .1 \mathrm{~B}$ & $1 \mathrm{~B}$ & $1 \mathrm{~A}$ & $1 \mathrm{~A}$ & \\
\hline \multirow[t]{5}{*}{ Epididymis } & Atrophy, right & $1 \mathrm{C}$ & & & & & -- & -- & -- & -- & -- \\
\hline & Dilation, duct, right & $1 \mathrm{C}$ & & & & & -- & -- & -- & -- & -- \\
\hline & Spermatid giant cells, duct, bilateral & & & & & $1 \mathrm{~A}$ & -- & -- & -- & -- & -- \\
\hline & & & $1 \mathrm{~B}$ & & & & -- & -- & -- & -- & -- \\
\hline & Spermatid giant cells, duct, unilateral & & $1 \mathrm{~B}$ & & & & -- & -- & -- & -- & -- \\
\hline \multirow{4}{*}{$\begin{array}{l}\text { Intestine, jejunum } \\
\text { Kidney }\end{array}$} & Hemorrhage, mucosa & & & $1 \mathrm{~B}$ & & & & & & & \\
\hline & Hyperplasia, transitional cell, bilateral & & & & & $1 \mathrm{C}$ & & & & & \\
\hline & Inflitration, lymphocytic & $2 \mathrm{~A}$ & $1 \mathrm{~A}$ & $1 \mathrm{~A}$ & $1 \mathrm{~A}$ & $2 \mathrm{~A}$ & $1 \mathrm{~A}$ & $1 \mathrm{~A}$ & $1 \mathrm{~A}$ & $3 \mathrm{~A}$ & $1 \mathrm{~A}$ \\
\hline & Vacuolation, cytoplasmic, & & & & & 1B & & & & & \\
\hline
\end{tabular}


Am. J. Pharm. \& Toxicol., 5 (4): 183-208, 2010

Table 13: Continue

\begin{tabular}{|c|c|c|c|c|c|c|c|c|c|c|c|}
\hline & transitional cell, bilateral & & & & & & & & & & \\
\hline Liver & Infiltration, lymphohistiocytic & & & & & & & & $1 \mathrm{~A}$ & & \\
\hline \multirow[t]{7}{*}{ Lung } & Foreign material, focal & & & & $1 \mathrm{~A}$ & & & & $1 \mathrm{~A}$ & & \\
\hline & Hemorrhage, bronchus & & 1B & & & & & & & & \\
\hline & Hyperplasia, lymphocytic & & & & & & & & & & $2 \mathrm{C}$ \\
\hline & $\begin{array}{l}\text { Infiltration, lymphohistiocytic } \\
\text { Inflammation, acute }\end{array}$ & $1 \mathrm{~A}$ & $2 \mathrm{~A}$ & $\begin{array}{l}2 \mathrm{~A}, \mathrm{~B} \\
2 \mathrm{C}\end{array}$ & $3 \mathrm{~A}$ & $2 \mathrm{~A}$ & $2 \mathrm{~A}, 1 \mathrm{~B}$ & $3 \mathrm{~A}$ & $3 \mathrm{~A}, 1 \mathrm{~B}$ & $2 \mathrm{~A}$ & \\
\hline & Inflammation, chronic, acute & & & & & 1D & & & & & \\
\hline & Inflammation, granulamatous & & $1 \mathrm{~A}$ & & $1 \mathrm{~A}$ & & & & $2 \mathrm{~A}$ & & \\
\hline & Abscess & & & & & 1D & & & & & \\
\hline \multirow[t]{4}{*}{ Lymph node, mediastinal } & Erythrophagocytosis & & & & & & & & & 1D & \\
\hline & Hemorrhage & & & 1B & & & & & & & \\
\hline & Mistiocytosis & & & 1B & & & & & & & \\
\hline & Inflammation, acute & & & & 1B & & & & & & \\
\hline Lymph node, mesenteric & Histiocytosis & & & 1B & & 1B & & & & & 1B \\
\hline Lymph node, bronchial & Hemorrhage & & & & & & & 1B & & & \\
\hline \multirow[t]{3}{*}{ Lymph node, mandibular } & Hemorrhage & & & & & & & & & 1B & \\
\hline & Histiocytosis & $2 \mathrm{~B}, 2 \mathrm{C}$ & & 1B & 1B & & $2 \mathrm{~B}$ & & & & \\
\hline & Infiltration, neutrophilic & & & & & & & & 1B & & \\
\hline Skeletal muscle & Infiltration, histiocytic & & & & & & & & $1 \mathrm{~A}$ & & \\
\hline Pancreas & Hemorrhage & & & 1B & & & & & & & \\
\hline Pituitary gland & Cyst, pars nervosa & & & & & & 1B & & $1 \mathrm{~A}$ & & \\
\hline $\begin{array}{l}\text { Salivary gland, } \\
\text { mandibular }\end{array}$ & Infiltration, luymphocytic & $2 \mathrm{~A}$ & $1 \mathrm{~A}$ & $1 \mathrm{~A}$ & $1 \mathrm{~A}$ & $1 \mathrm{~A}$ & $2 \mathrm{~A}$ & $2 \mathrm{~A}$ & & & \\
\hline Skin, abdominal & Inflammation, chronic & & & & & & & & $1 \mathrm{~A}$ & & \\
\hline \multirow[t]{4}{*}{ Skin, treated sites } & Inflammation, chronic, focal & & & 1B & & & & & & & \\
\hline & Hyperkeratosis, focal & & & 1B & & & & & & & \\
\hline & Abscess & & & & & $1 \mathrm{D}$ & & & & & \\
\hline & Inflammation, ulcerative & & & $1 \mathrm{C}$ & & 1D & & & & & \\
\hline \multirow[t]{5}{*}{ Skin, untreated } & Inflammation, chronic & & $1 \mathrm{C}$ & 1B & & & & $1 \mathrm{~B}, 1 \mathrm{C}$ & & & \\
\hline & Inflammation, ulcerative, focal & & & $1 \mathrm{C}$ & & 1D & 1D & $1 \mathrm{D}$ & & 1B & 1B \\
\hline & Hyperkeratosis & & 1B & $1 \mathrm{C}$ & & 1B & $2 \mathrm{~B}$ & $1 \mathrm{~B}, 1 \mathrm{C}$ & & $1 \mathrm{C}$ & 1B \\
\hline & Hyperkeratosis, focal & & & & & & $1 \mathrm{C}$ & & & & \\
\hline & Hemorrhage, subcutaneous & & & & & & $1 \mathrm{C}$ & & & & \\
\hline Spinal cord, cervical & Hemorrhage, multifocal & & & & & & & & $1 \mathrm{~A}$ & & \\
\hline Spinal cord, thoracic & Hemorrhage, multifocal & $1 \mathrm{~A}$ & $1 \mathrm{~A}$ & & $1 \mathrm{~A}$ & & $2 \mathrm{~A}$ & $1 \mathrm{~A}$ & & $1 \mathrm{~A}$ & \\
\hline Spinal cord, lumbar & Hemorrhage, multifocal & $1 \mathrm{~A}$ & & & & & & & & & \\
\hline Stomach & Hemorrhage, mucosa & & & 1B & & & & & & & \\
\hline \multirow[t]{4}{*}{ Testis } & Atrophy, right & $1 \mathrm{C}$ & & & & & -- & -- & -- & -- & -- \\
\hline & $\begin{array}{l}\text { Degeneration, seminiferous } \\
\text { tubule, germinal epithelium }\end{array}$ & & & & 1B & & -- & -- & -- & -- & -- \\
\hline & $\begin{array}{l}\text { Spermatid giant cells, } \\
\text { seminiferous tubule, bilateral }\end{array}$ & & 1B & & & 1B & -- & -- & -- & -- & -- \\
\hline & $\begin{array}{l}\text { Spermatid giant cells, } \\
\text { seminiferous tubule, unilateral }\end{array}$ & & 1B & & 1B & 1B & -- & -- & -- & -- & -- \\
\hline \multirow[t]{6}{*}{ Thymus } & Depletion & & & & & & & & & & 1D \\
\hline & Edema & & & & & & $1 \mathrm{C}$ & & & & \\
\hline & Hemorrhage & & & $1 \mathrm{C}$ & & & $1 \mathrm{C}$ & & & & \\
\hline & Infiltration, neutrophilic & & 1B & & & & & & & & \\
\hline & Involution & & & & & 1B & & & & & \\
\hline & Fibrosis & & & & & & & & & & 1D \\
\hline Thyroid gland & Hemorrhage & & & & & & $1 \mathrm{C}$ & & & & \\
\hline Tongue & Hemorrhage & & & & & 1B & & & & & \\
\hline Treachea & Infiltration, lymphocytic & & 1B & & & & & & & & \\
\hline
\end{tabular}

Since BALT is prominent in this species, moderate hyperplasia is not considered biologically significant. Minimal or mild multifocal hemorrhage in the brain and/or spinal cord was noted in animals from most groups (control and treatment groups included) and was most likely associated with removal of the tissue at necropsy.

Total (free plus bound) plasma concentrations of CPI-613 and toxicokinetics: The plasma CPI-613 concentrations after administrations of different doses of CPI-613 were assessed in rats in Experiment A.
These concentration-time curves of CPI-613 (Fig. 4) revealed an apparent 2-compartment model with biphasic appearance, characterized by an initial distribution phase followed by a terminal elimination phase with a terminal half-life $\left(\mathrm{T}_{1 / 2}\right)$ of approximately 2-5 hours. The onset of the terminal phase was between 1-8 hours post dose. There were no apparent differences in these results between genders. Interestingly, there were no statistical differences among different dose groups, possibly because of the narrow dose range used in this study. 
Am. J. Pharm. \& Toxicol., 5 (4): 183-208, 2010

Table 14: Pharmacokinetics (PKs) in rats from Experiment A. PK results presented in this table are combined results from males and females, due to a lack of apparent difference in these values between the two sexes

\begin{tabular}{|c|c|c|c|c|c|c|c|c|c|c|c|c|}
\hline \multirow[b]{2}{*}{ Dose } & \multicolumn{3}{|l|}{$\begin{array}{l}\text { Day } 1 \\
1^{\text {st }} \text { Dose }\end{array}$} & \multicolumn{3}{|l|}{$\begin{array}{l}\text { Day } 4 \\
2^{\text {nd }} \text { Dose }\end{array}$} & \multicolumn{3}{|l|}{$\begin{array}{l}\text { Day } 11 \\
4^{\text {th }} \text { Dose }\end{array}$} & \multicolumn{3}{|c|}{$\begin{array}{l}\text { Day } 18 \\
6^{\text {th }} \text { Dose }\end{array}$} \\
\hline & $\begin{array}{l}25 \\
150\end{array}$ & $\begin{array}{l}30 \\
180\end{array}$ & $\begin{array}{l}35 \\
210\end{array}$ & $\begin{array}{l}25 \\
150\end{array}$ & $\begin{array}{l}30 \\
180 \\
\end{array}$ & $\begin{array}{l}35 \\
210 \\
\end{array}$ & $\begin{array}{l}25 \\
150 \\
\end{array}$ & $\begin{array}{l}30 \\
180 \\
\end{array}$ & $\begin{array}{l}35 \\
210\end{array}$ & $\begin{array}{l}25 \\
150\end{array}$ & $\begin{array}{l}30 \\
180 \\
\end{array}$ & $\begin{array}{l}35 \\
210 \\
\end{array}$ \\
\hline $\mathrm{C}_{\max }\left(\mathrm{ng} / \mathrm{mL} \times 10^{3}\right)$ & 35.30 & 47.90 & 56.50 & 16.00 & 31.00 & 42.60 & 29.60 & 41.90 & 77.50 & 14.60 & 27.50 & 41.40 \\
\hline $\mathrm{C}_{\max } /$ Dose (ng.kg/mL.mg) & 411.00 & 597.00 & 1614.00 & 640.00 & 1033.00 & 1218.00 & 1182.00 & 1395.00 & 2214.00 & 586.00 & 916.00 & 1183.00 \\
\hline $\mathrm{AUC}_{0-24 \mathrm{hr}}\left(\mathrm{ng} . \mathrm{h} / \mathrm{mL} \times 10^{3}\right)$ & 18.20 & 25.80 & 26.20 & 13.70 & 19.20 & 23.90 & 16.90 & 24.30 & 32.30 & 12.50 & 19.40 & 23.50 \\
\hline $\operatorname{AUC}_{0-\infty}\left(\mathrm{ng} \cdot \mathrm{h} / \mathrm{mL} \times 10^{3}\right)$ & 18.20 & 26.00 & 26.30 & 13.80 & 19.30 & 17.20 & 17.10 & 24.50 & 37.80 & 12.60 & 19.50 & 20.60 \\
\hline $\mathrm{AUC}_{24-\infty} / \mathrm{AUC}_{0-\infty}(\%)$ & 0.23 & 0.70 & 0.22 & 0.55 & 0.46 & 0.49 & 1.17 & 0.48 & 0.48 & 0.74 & 0.40 & 1.10 \\
\hline $\mathrm{AUC}_{0-24 \mathrm{hr}} /$ Dose (ng.kg/mL.mg) & 727.00 & 862.00 & 750.00 & 49.00 & 641.00 & 682.00 & 676.00 & 812.00 & 922.00 & 501.00 & 648.00 & 671.00 \\
\hline $\mathrm{K}_{\mathrm{el}}(/ \mathrm{h})$ & 0.18 & 0.15 & 0.19 & 0.17 & 0.17 & 0.17 & 0.12 & 0.22 & 0.18 & 0.16 & 0.20 & 0.11 \\
\hline Terminal $\mathrm{T}_{1 / 2}(\mathrm{~h})$ & 4.07 & 4.78 & 3.74 & 4.16 & 4.05 & 4.06 & 6.71 & 3.18 & 3.84 & 4.93 & 3.66 & 6.47 \\
\hline $\mathrm{Vd}\left(\mathrm{mL} / \mathrm{kg} \times 10^{3}\right)$ & 8.30 & 8.00 & 7.20 & 11.00 & 9.70 & 11.90 & 15.50 & 5.60 & 5.10 & 14.20 & 8.20 & 15.90 \\
\hline $\mathrm{Cl}\left(\mathrm{mL} \mathrm{h}^{-1} \mathrm{~kg}^{-1}\right)$ & 1502.00 & 1154.00 & 1335.00 & 1825.00 & 1648.00 & 2031.00 & 1513.00 & 1227.00 & 926.00 & 1984.00 & 1545.00 & 1703.00 \\
\hline
\end{tabular}

$\mathrm{AUC}_{0-24 \mathrm{~h}}=$ Area Under the Curve (AUC) from dosing time to the final observation at $24 \mathrm{~h}$; AUC $0-\infty=$ area under the curve from the dosing time extrapolated to infinity; $\mathrm{Cl}=$ total body clearance; $\mathrm{C}_{\max }=$ maximum observed concentration extrapolated to time 0 min; $\mathrm{K}_{\mathrm{el}}=$ terminal elimination phase rate constant; Terminal $\mathrm{T}_{1 / 2}=$ plasma half-life derived from the second or terminal phase of elimination; Vd= apparent volume of distribution

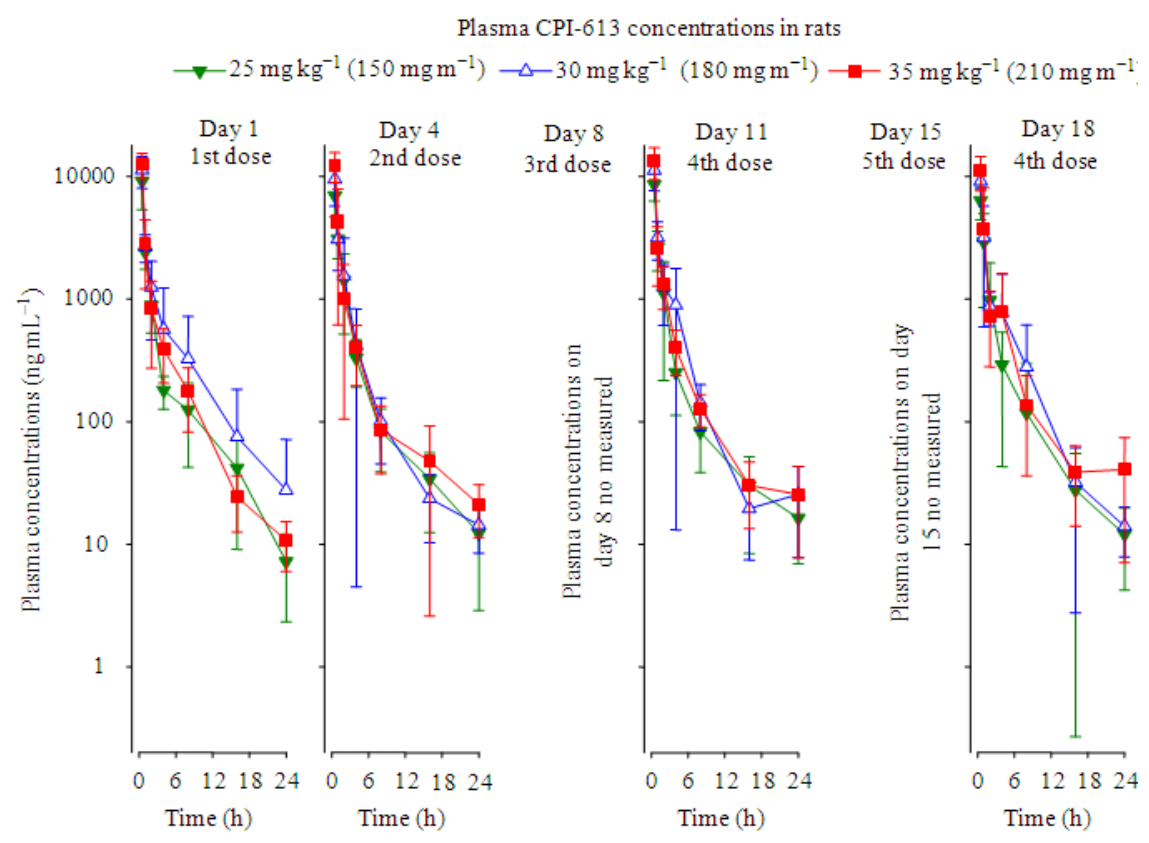

Fig. 4: Plasma concentrations of CPI-613 in rats treated with 25,30 or $35 \mathrm{mg} \mathrm{kg}^{-1}$ of CPI-613, given $2 \mathrm{x}$ weekly for three consecutive weeks from Experiment A. There were 4 rats per sex at each time point of each dose level. Results are presented as mean \pm standard of deviation

The PK results, derived from group mean values of plasma CPI-613 concentrations, are shown in Table 14. Significant amounts of CPI-613 were detected $24 \mathrm{~h}$ after each of the 6 administrations of CPI-613. Despite detectable concentrations of CPI-613 at $24 \mathrm{~h}$ post dose, there was no evidence of accumulation of CPI-613 associated with the "twice weekly for 3 weeks" dosing regimen. The lack of drug accumulation and a terminal $\mathrm{T}_{1 / 2}$ of $2-5 \mathrm{~h}$ indicated that a single administration is representative of the steady state kinetics at the dose levels tested with this dosing regimen.
The apparent volume of distribution (Vd) and total body clearance $(\mathrm{Cl})$ of CPI-613 were estimated beyond physiological meaning, with considerable variability in the volume parameter. These results suggested that the distribution was thorough and clearance was rapid.

The values of the maximum observed concentration extrapolated to time 0 ( Cmax) and AUC from dosing time to the final observation at $24 \mathrm{~h}\left(\mathrm{AUC}_{0-24 \mathrm{hr}}\right)$ were proportional to dose levels (Fig. 5). 
Am. J. Pharm. \& Toxicol., 5 (4): 183-208, 2010

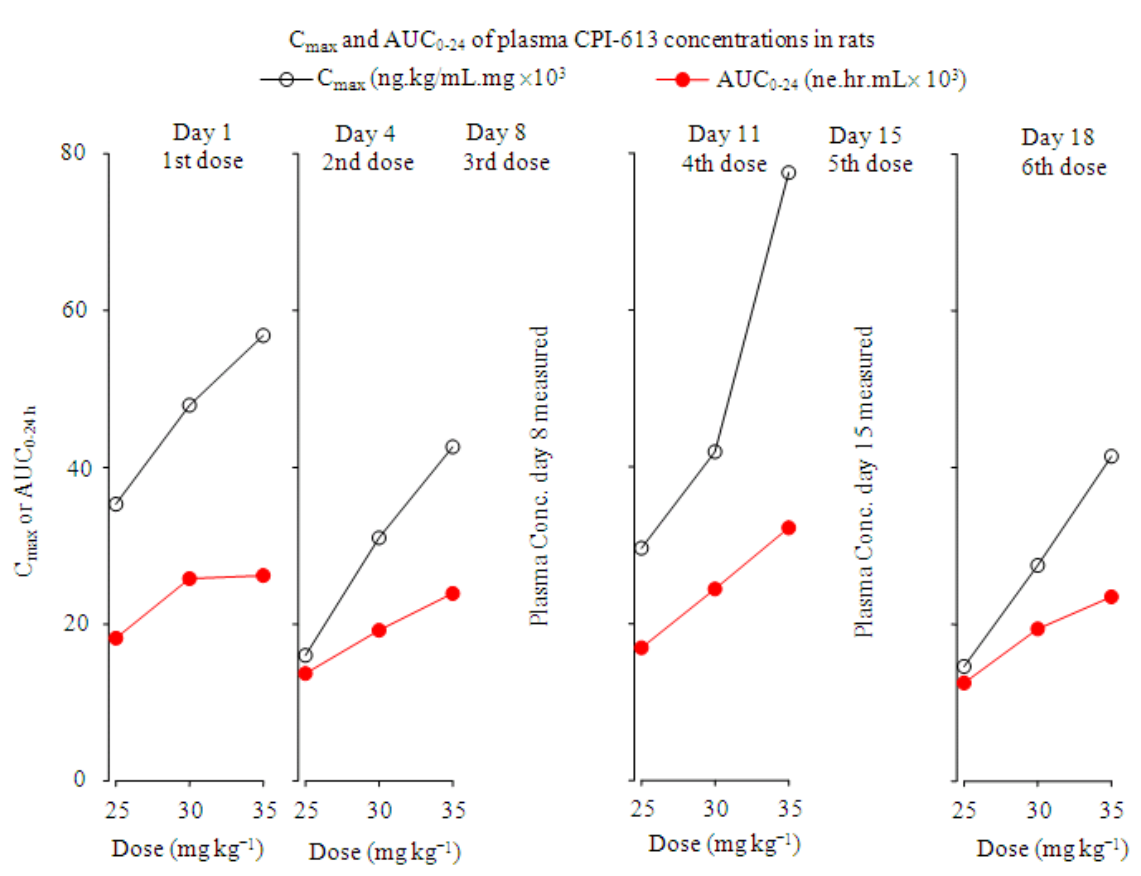

Fig. 5: Area under the curve from dosing time to the final observation at $24 \mathrm{~h}\left(\mathrm{AUC}_{0-24 \mathrm{~h}}\right)$ and maximum observed concentration extrapolated to time at $0 \mathrm{~h}\left(\mathrm{C}_{\max }\right)$ in rats treated with intravenous CPI-613 at 25,30 or 35 $\mathrm{mg} / \mathrm{kg}$, given 2x weekly for three consecutive weeks from Experiment A. These pharmacokinetic parameters were derived from the mean values of 4 rats per sex at each time point at each dose level

\section{DISCUSSION}

Study objectives and rationale: The objective of these studies was to systematically investigate the doserelated TK effects of CPI-613 in rats. The objective of these studies was also to investigate the toxicological profile of CPI-613 in minipigs, to determine if there were differences in the toxicological profile and sensitivity of CPI-613 between these two animal species. CPI-613 was given IV twice weekly for three consecutive weeks in both animal species. The "twice weekly for three weeks" dosing schedule was the intended clinical dosing schedule and results from these studies may provide insight to possible adverse events in study subjects of clinical trials. The investigation of these doses helped to determine the safety of CPI-613 and to reveal the potential toxicity associated with CPI613. Also, these toxic doses of CPI-613 were $\sim 60 \mathrm{x}$ the anti-tumor dose levels observed in mouse tumor xenograft models, suggesting a wide safety margin of CPI-613.

The results from these studies revealed the uncommon toxicological profile at toxic doses of CPI613 , which were related to induction of inflammation as the primary and possibly the only toxicological effects, in both rats and minipigs. The severity of the inflammatory effect was consistent with the doserelated increases in plasma CPI-613. Other changes such as elevations in reticulocytes and GGT) were also observed, but they might be secondary to the inflammatory effects of CPI-613.

Assessment of dose-related toxicity, recovery and PK of CPI-613 in rats: In the rat studies, the criteria for choosing the three doses, which were based on results from previous preliminary studies, were that the lowest dose would induce minimum effects (i.e., the threshold dose), the mid-dose would induce significant toxic effects and the highest dose would approximate the $\mathrm{LD}_{10}$. Based on these criteria for selecting the doses in these studies, the dose range turned out to be relatively narrow and was $25-35 \mathrm{mg} \mathrm{kg}^{-1}$ for rats. These studies were also for evaluation of reversibility of the toxic effects of CPI-613, by comparing the intensity of toxic effects of CPI-613 immediately after treatment with CPI-613 vs. those two weeks after the last dose of CPI-613. The results showed that all toxic effects of CPI-613 were reversible.

The major toxic effect of CPI-613 in rats was inflammation. Inflammation occurred beyond the injection site and the severity of inflammation-related symptoms was mostly related to the dose levels. As a 
matter of fact, the cause of death or moribund condition after treatment with CPI-613 revealed significant systemic inflammation. Inflammation being the primary toxicity at toxicological/lethal doses of CPI-613 was supported by necropsy and histological assessments. Systemic inflammation, which was nicely reviewed by (Nystrom, 1998), is similar to sepsis, except that it was not of microbial etiology. Regulation of the immune system by chemotherapeutic agents has previously been reported (Barret and Blanc, 2009).

The exact mechanism for the inflammatory effects of CPI-613 is unknown. A possible explanation may be related to non-specific chemical effects of CPI-613, since this compound has some detergent-like structural properties. High local concentrations of detergents (which occur at the site of injection) can induce local inflammation-like effects (Krob et al., 2004; Shaw et al., 2004). Another possible explanation is that, although selectively effective against tumor cells, high concentration (as occurs at the site of injection) can induce adverse effects or death in normal cells, leading to inflammation. Regardless of the mechanism of action for inflammatory effects of CPI-613, the severity and frequency can be attenuated or even eliminated by lowering the concentrations of injectate, slowing the rate of infusion of CPI-613, or both. This is consistent with our experience to date in animal safety studies as well as ongoing clinical trials (Retter et al., 2010). An approach to eliminate local inflammation at the site of injection of a peripheral vein is to infuse CPI-613 via a central venous catheter. This approach was implemented once we learned that CPI-613 still induces local reaction even with dilution of the injectate and slow rate of infusion of CPI-613, which is currently the route of administration in ongoing clinical trials of CPI-613.

In rats, increases in reticulocytes and GGT were observed after treatment with high doses of CPI-613. The rise in reticulocytes may be associated with hematopoietic cell proliferation of the spleen and sternal bone marrow hyperplasia, which are considered secondary to inflammation initiated at the administration site or port rather than primary effects of CPI-613. The indirect nature of CPI-613 effects on the rise of reticulocytes is further supported by a lack of effects on other blood cell counts. For the rise in GGT in high doses of CPI-613, although it could reflect injury of the kidney and liver, it was not associated with histopathology findings or other parameters of kidney or liver functions. Therefore, the elevation was unlikely related to toxicity of the kidney or liver. Rather, it may be related to systemic inflammation, as reported by (Yamada et al., 2006).

PK was assessed concurrently with toxicological evaluation. The TK profile of CPI-613 was characterized by an apparent 2-compartment model with biphasic appearance. Systemic exposure to CPI613 was proportional to dose level in rats and there was no evidence of test article accumulation or sex differences in CPI-613 exposure.

Assessment of dose-related toxicity of CPI-613 in minipigs: The toxicological effects at toxic doses of CPI-613 were also assessed in minipigs. The nature of the toxicological effects (such as inflammation at the site of injections and symptoms of systemic inflammation) were similar to rats. However, minipigs were less sensitive to the toxicological effects of CPI613 than rats, as reflected by the toxic dose of CPI-613 in minipigs $\left(\sim 55 \mathrm{mg} \mathrm{kg}^{-1}\right.$ or $\left.\sim 1925 \mathrm{mg}^{-1} \mathrm{~m}^{2}\right)$ being significantly higher than those of rats $\left(30-35 \mathrm{mg} \mathrm{kg}^{-1}\right.$ or $180-210 \mathrm{mg}^{-1} \mathrm{~m}^{2}$ ).

\section{CONCLUSION}

These studies demonstrated the uncommon toxicological profile at toxic doses of CPI-613, which were related to induction of inflammation as the primary and possibly the only toxicological effects, in both rats and minipigs. The severity of the inflammatory effects correlated with the dose-related increases in plasma CPI-613. Other changes such as elevations in reticulocytes and Gamma-Glutamyl Transferase (GGT) were also observed, but they might be secondary to the inflammatory effects of CPI-613. This uncommon toxicological profile of CPI-613 reflects its novel mechanism of action.

The TK profile of CPI-613 was characterized by an apparent 2-compartment model with biphasic appearance. Systemic exposure to CPI-613 was proportional to dose level, with no evidence of test article accumulation or sex differences in CPI-613 exposure.

Additionally, the toxic doses of CPI-613 observed in these study were $\sim 60 \mathrm{x}$ the anti-tumor dose levels observed in mouse tumor xenograft models, suggesting a wide safety margin of CPI-613. Therefore, the dose of CPI-613 to be used in the clinic is expected to be significantly below the sub-lethal dose and the risk of CPI613 inducing significant toxicity in the clinic is unlikely.

\section{ACKNOWLEDGEMENT}

Researchers gratefully acknowledge the contributions of Ms. Kathleen O'Donnell (Cornerstone Pharmaceuticals, Inc.) for her contributions in reviewing and editing of this manuscript.

\section{REFERENCES}

Baggetto, L.G., 1992. Deviant energetic metabolism of glycolytic cancer cells. Biochimie, 74: 959-974. DOI: 10.1016/0300-9084(92)90016-8 
Barret, J. and K.L. Blanc, 2009. Cancer Chemotherapy and Immune Regulation. Am. J. Immunol., 5: 8-16. DOI: $10.3844 /$ ajisp.2009.8.16

Freireich, E.J., E.A. Gehan, D.P. Rall, L.H. Schmidt and H.E. Skipper, 1966. Quantitative comparison of toxicity of anticancer agents in mouse, rat, hamster, dog, monkey, and man. Cancer Chemother Rep., 50: 219-244. PMID: 4957125

Holmuhamedov, E., L. Lewis, M. Bienengraeber, M. Holmuhamedova and A. Jahangir et al., 2002. Suppression of human tumor cell proliferation through mitochondrial targeting. FASEB J., 16: 1010-1016. DOI: 10.1096/fj.01-0996com

Kim, J.W. and C.V. Dang, 2006. Cancer's molecular sweet tooth and the Warburg effect. Cancer Res., 66: 8927-8930. DOI: 10.1158/0008-5472.CAN-061501

Krob, H.A., A.B. Fleischer, Jr., R. D'Agostino, Jr., C.L. Haverstock and S. Feldman, 2004. Prevalence and relevance of contact dermatitis allergens: A metaanalysis of 15 years of published T.R.U.E. test data. J. Am. Acad. Dermatol., 51: 349-353. PMID: 15337975

Kroemer, G. and J. Pouyssegur, 2008. Tumor cell metabolism: Cancer's Achilles' heel. Cancer Cell, 13: 472-482. DOI: 10.1016/j.ccr.2008.05.005

Nunoya, T., K. Shibuya, T. Saitoh, H. Yazawa and K. Nakamura et al., 2007. Use of miniature pig for biomedical research, with reference to toxicologic studies. J. Toxicol. Pathol., 20: 125-132. DOI: 10.1293/tox. 20.125

Nystrom, P.O., 1998. The systemic inflammatory response syndrome: Definitions and aetiology. J. Antimicrob. Chemother., 41: 1-7. DOI: 10.1093/jac/41.suppl_1.1
Ravindran, S., G.A. Radke, J.R. Guest and T.E. Roche, 1996. Lipoyl domain-based mechanism for the integrated feedback control of the pyruvate dehydrogenase complex by enhancement of pyruvate dehydrogenase kinase activity. J. Biol. Chem., 271: 653-662. DOI: 10.1074/jbc.271.2.653

Retter, A.S., R. Shorr, R. Rodriguez, K. Hoffman and F. Volterra et al., 2010. Phase I trial of CPI-613, a lipoic acid analog, and gemcitabine in patients with advanced solid tumors. ASCO, Chicago, IL. http://www.asco.org/ASCOv2/Meetings/Abstracts? \&vmview=abst_detail_view\&confID=74\&abstract $\mathrm{ID}=43689$

Sakkrom, P., W. Pompimon, P. Meepowpan, N. Nuntasaen and C. Loetchutinat, 2010. The effect of phyllanthus taxodiifolius beille extracts and its triterpenoids studying on cellular energetic stage of cancer cells. Am. J. of Pharmacology and Toxicology, 5: 139-144. DOI: 10.3844/ajptsp.2010.139.144

Shaw, D.W., L.F. Eichenfield, T. Shainhouse and H.I. Maibach, 2004. Allergic contact dermatitis from tacrolimus. J. Am. Acad. Dermatol., 50: 962-965. DOI: $10.1016 /$ j.jaad.2003.09.013

Swindle, M.M., 2007. Swine in the Laboratory: Surgery, Anesthesia, Imaging and Experimental Techniques. 2nd Edn., CRC Press, Boca Raton, FL., ISBN-10: 0849392780, pp: 471.

Yamada, J., H. Tomiyama, M. Yambe, Y. Koji and K. Motobe et al., 2006. Elevated serum levels of alanine aminotransferase and gamma glutamyltransferase are markers of inflammation and oxidative stress independent of the metabolic syndrome. Athero, 189: 198-205. DOI: 10.1016/j.atherosclerosis.2005.11.036 